\title{
Analysis of Cascade Impactor and EPA Method 29 Data from the Americium/Curium Pilot Melter System
}

by

J. R. Zamecnik

Westinghouse Savannah River Company

Savannah River Site

Aiken, South Carolina 29808

This paper was prepared in connection with work done under the above contract number with the U.S.

Department of Energy. By acceptance of this paper, the publisher and/or recipient acknowledges the U. S. Government's right to retain a nonexclusive, royalty-free license in and to any copyright covering this paper, along with the right to reproduce and to authorize others to reproduce all or part of the copyrighted paper. 


\section{DISCLAIMER}

Portions of this document may be illegible electronic image products. Images are produced from the best available original document. 


\section{DISCLAIMER}

This report was prepared as an account of work sponsored by an agency of the United States Government. Neither the United States Government nor any agency thereof, nor any of their employees, makes any warranty, express or implied, or assumes any legal liability or responsibility for the accuracy, completeness, or usefulness of any information, apparatus, product, or process disclosed, or represents that its use would not infringe privately owned rights. Reference herein to any specific commercial product, process, or service by trade name, trademark, manufacturer, or otherwise does not necessarily constitute or imply its endorsement, recommendation, or favoring by the United States Government or any agency thereof. The views and opinions of authors expressed herein do not necessarily state or reflect those of the United States Government or any agency thereof.

This report has been reproduced directly from the best available copy.

Available to DOE and DOE contractors from the Office of Scientific and Technical Information, P. O. Box 62, Oak Ridge, TN 37831; prices available from (423) 576-8401.

Available to the public from the National Technical Information Service, U. S. Department of Commerce, 5285 Port Royal Road, Springfield, VA 22161. 


\section{DISTRIBUTION:}

G. T. Wright, 773-A

L. M. Papouchado, 773-A

J. D. Cohen, 773-A

J. E. Marra, 704-T

E. W. Holtzscheiter, 773-A

L. F. Landon, 704-1T

C. T. Randall, 704-T

C. R. Goetzman, 773-A

D. A. Crowley, 773-43A

N. E. Bibler, 773-A

J. R. Harbour, 773-43A

D. F. Bickford, 773-43A

D. C. Witt, 704-1T

D. H. Miller, 704-1T

M. E. Smith, 704-1T

A. S. Choi, 704-1T

T. M. Jones, 704-1T

M. E. Stone, 704-T

R. F. Schumacher, 773-43A

D. K. Peeler, 773-43A

J. R. Zamecnik, 773-41A

D. R. Best, 773-A

E. M. Frickey, 773-23A

T. B. Calloway, 773-41A

D. S. McIntyre, 773-A

A. Cozzi, 773-A

J. C. Whitehouse, 723-A

STI, 703-43A (4) 


\section{ANALYSIS OF CASCADE IMPACTOR AND EPA METHOD 29 DATA FROM THE AMERICIUM/CURIUM PILOT MELTER SYSTEM (U)}

Author: John R. Zamecnik

Publication Date: November 19, 1997

Keywords: particulate sampling, lead oxide, lanthanides, HEME, quencher, scrubber

Retention: Permanent
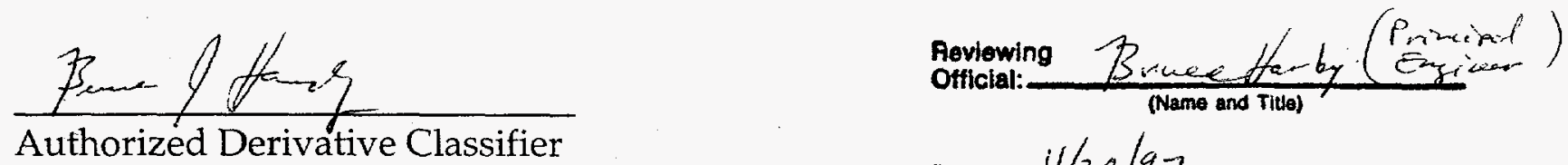

Date: $11 / 20 / 97$ 
This report was prepared by Westinghouse Savannah River Company (WSRC) for the United States Department of Energy under Contract No. DE-AC09-89SR18035 and is an account of work performed under that contract. Neither the United States Department of Energy, nor WSRC, nor any of their employees makes any warranty, expressed or implied, or assumes any legal liability or responsibility for the accuracy, completeness, or usefulness, of any information, apparatus, or product or process disclosed herein or represents that its use will not infringe privately owned rights. Reference herein to any specific commercial product, process, or service by trademark, name, manufacturer or otherwise does not necessarily constitute or imply endorsement, recommendation, or favoring of same by WSRC or by the United States Government or any agency thereof. The views and opinions of the authors expressed herein do not necessarily state or reflect those of the United States Government or any agency thereof. 
WSRC-RP-97-00937, Rev. 0

APPROVALS

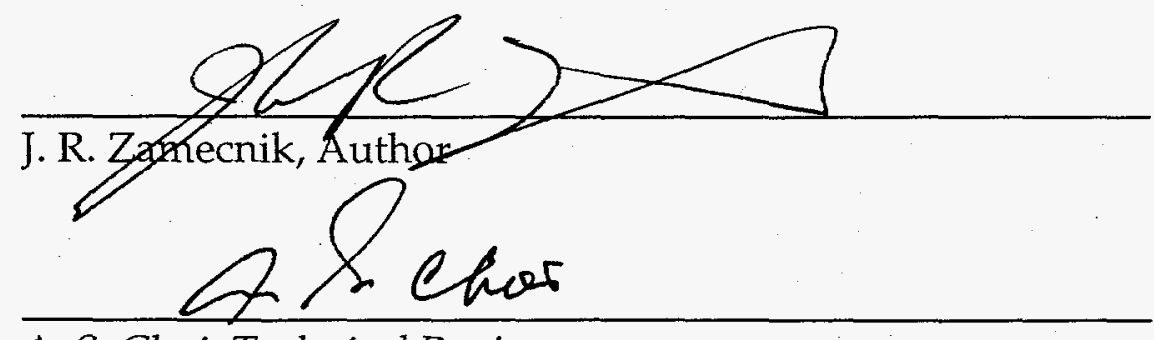

A. S. Choir, Technical Reviewer

Quid A. Cowley

D. A. Crowley, Manager, Glass Formulation \& Melter Tech.

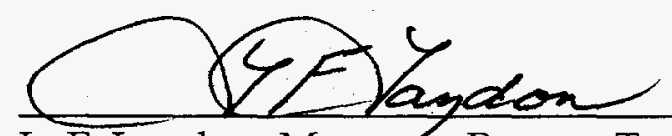

L. F. Landon, Manager, Process Technology Development
$11-20-97$

Date

$\frac{11-20-97}{\text { Date }}$

$11 / 20 / 97$

Date

$\frac{1)-20-97}{\text { Date }}$ 


\section{SUMMARY}

The offgas system of the Am/Cm pilot melter at TNX was characterized by measuring the particulate evolution using a cascade impactor and EPA Method 29. This sampling work was performed by John Harden of the Clemson Environmental Technologies Laboratory, under SCUREF Task SC0056. Elemental analyses were performed by the SRTC Mobile Laboratory.

Operation of the Am/Cm melter with B2000 frit has resulted in deposition of $\mathrm{PbO}$ and boron compounds in the offgas system that has contributed to pluggage of the High Efficiency Mist Eliminator (HEME). Sampling of the offgas system was performed to quantify the amount of particulate in the offgas system under several sets of conditions. Particulate concentration and particle size distribution were measured just downstream of the melter pressure control air addition port and at the HEME inlet. At both locations, the particulate was measured with and without steam to the film cooler while the melter was idled at about $1450^{\circ} \mathrm{C}$. Additional determinations were made at the melter location during feeding and during idling at $1150^{\circ} \mathrm{C}$ rather than $1450^{\circ} \mathrm{C}$ (both with no steam to the film cooler). Deposition of particulates upstream of the melter sample point may have, and most likely did occur in each run, so the particulate concentrations measured do not necessarily reflect the total particulate emission at the melt surface. However, the data may be used in a relative sense to judge the system performance.

During idling of the melter at $1450^{\circ} \mathrm{C}, 63 \%$ of the particulate emitted was found to be $\mathrm{PbO}$. Most of the remainder was probably boron compounds, but this could not be determined conclusively due to difficulties with the analytical measurements of boron. The total and $\mathrm{PbO}$ emission rates were 9.00 and $5.65 \mathrm{mg} / \mathrm{min}$, respectively. Idling at $1150^{\circ} \mathrm{C}$ reduced the total particulate emissions from $9.00 \mathrm{mg} / \mathrm{min}$ to $0.21 \mathrm{mg} / \mathrm{min}$ or less. Although no $\mathrm{PbO}$ was detected in the sample (below detection limit) at $1150^{\circ} \mathrm{C}$, it is likely that about $1 / 2$ of the particulate was $\mathrm{PbO}$. The particle size of the $\mathrm{PbO}$ emissions during idling was generally less than about $0.3 \mu \mathrm{m}$.

During feeding of coupled surrogate feed/frit, about $85 \mathrm{wt} \%$ of the particulate collected was larger than $1 \mu \mathrm{m}$ and the total particulate emission rate was about $10 \mathrm{X}$ the rate measured during idling at $1450^{\circ} \mathrm{C}$. During feeding, most of the particulate measured by elemental analysis was entrained feed surrogate. The remainder is volatilized $\mathrm{PbO}$ (and probably boron compounds). The presence of the cold cap during feeding reduced the evolution of $\mathrm{PbO}$ from 5.65 to $2.21 \mathrm{mg} / \mathrm{min}$. The reduction in evolution of $\mathrm{PbO}$ during feeding is most likely due to the reduced glass surface temperature and the coverage of the glass surface by the cold cap.

The use of steam to the film cooler was found to decrease the $\mathrm{PbO}$ emissions during idling. The most likely reason for this behavior is that the steam cooled the melt surface more than the equivalent amount of air. The reduction in total emissions was found to be about 1.5-2X. The use of steam to the film cooler was also found to remove deposits on the film cooler and offgas line; "cleaned" material from the previous run with feed 
was found in the sampling train; inspection of the offgas line after use of steam to the film cooler showed few deposits. This result is consistent with visual observations of the system after previous inspections.

The use of steam to the film cooler increases the efficiency of particulate removal prior to the HEME from about $10 \%$ to $60-70 \%$. This increase appears to be due to an increase in the efficiency of the quencher/scrubber.

\section{BACKGROUND}

Offgas samples were taken at the exit of the melter downstream of the film cooler and the control air addition port, and downstream of the condensate tank just prior to the High Efficiency Mist Eliminator (HEME), as shown in Figure 1. These analyses were desired due to a significant problem with plugging of the HEME during operation. The current design basis frit for the Am/Cm project, B2000, contains a substantial amount of lead oxide $(\mathrm{PbO})$, which is easily volatilized at the melter operating temperature. The composition of the B2000 frit is shown in Table I.

\section{Table I. B2000 Frit Composition}

\begin{tabular}{||cc|}
\hline Oxide & Weight Percent \\
\hline $\mathrm{SiO}_{2}$ & 43.96 \\
$\mathrm{~B}_{2} \mathrm{O}_{3}$ & 9.72 \\
$\mathrm{AlO}_{2}$ & 5.63 \\
$\mathrm{LaO}_{2}$ & 7.22 \\
$\mathrm{PbO}$ & 24.15 \\
$\mathrm{BaO}$ & 9.32 \\
\hline
\end{tabular}

The normal operating temperature of the melter is. $1450^{\circ} \mathrm{C}$, as measured at the melter wall. The actual glass temperature has been estimated to be about 30 to $50^{\circ} \mathrm{C}$ less than the measured temperature. The temperatures referred to herein are the measured temperatures at the melter wall.

Plugging of the clean HEME occurred within 3 to 5 hours of operation both during feeding of coupled surrogate feed/frit and idling at normal operating temperature. Therefore, it was desired that quantification of the evolution of particulate material during both idling and feeding be conducted. The use of steam to the film cooler had been hypothesized as a method to reduce particulate buildup in the offgas system, so quantification with and without steam was also desired. In addition to determining the total particulate evolution, the particle size distribution and elemental composition of the particulate in total and as a function of particle size was desired. Therefore, a cascade impactor, which separates particles by aerodynamic size, and the EPA Method 29 sampling train, which is used to determine the elemental composition of particulate metals, were combined and used to sample the process. 


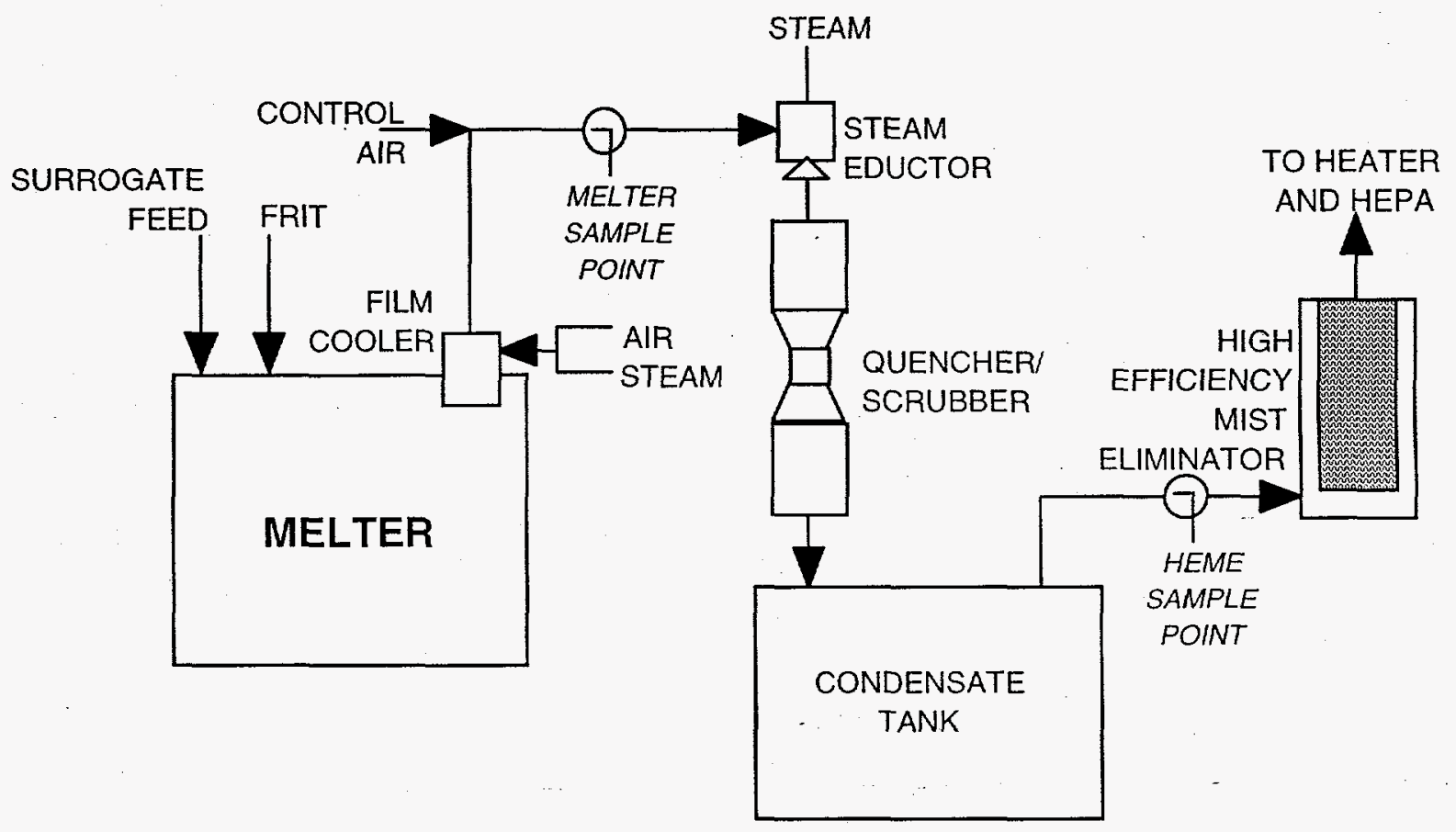

Figure 1. Simplified Schematic of the Am/Cm Offgas System

\section{EXPERIMENTAL}

A diagram of the experimental sampling equipment is shown in Figure 2. The offgas system sampling points consisted of approximately $3 / 8^{\prime \prime}$ slots cut in the 2 " sch. 40 offgas line into which a "buttonhook" sampling probe was installed. This sample probe is designed to face directly into the process stream, so isokinetic (equal velocity) sampling can be conducted. The probe used had an inside diameter of $5 / 16^{\prime \prime}$.

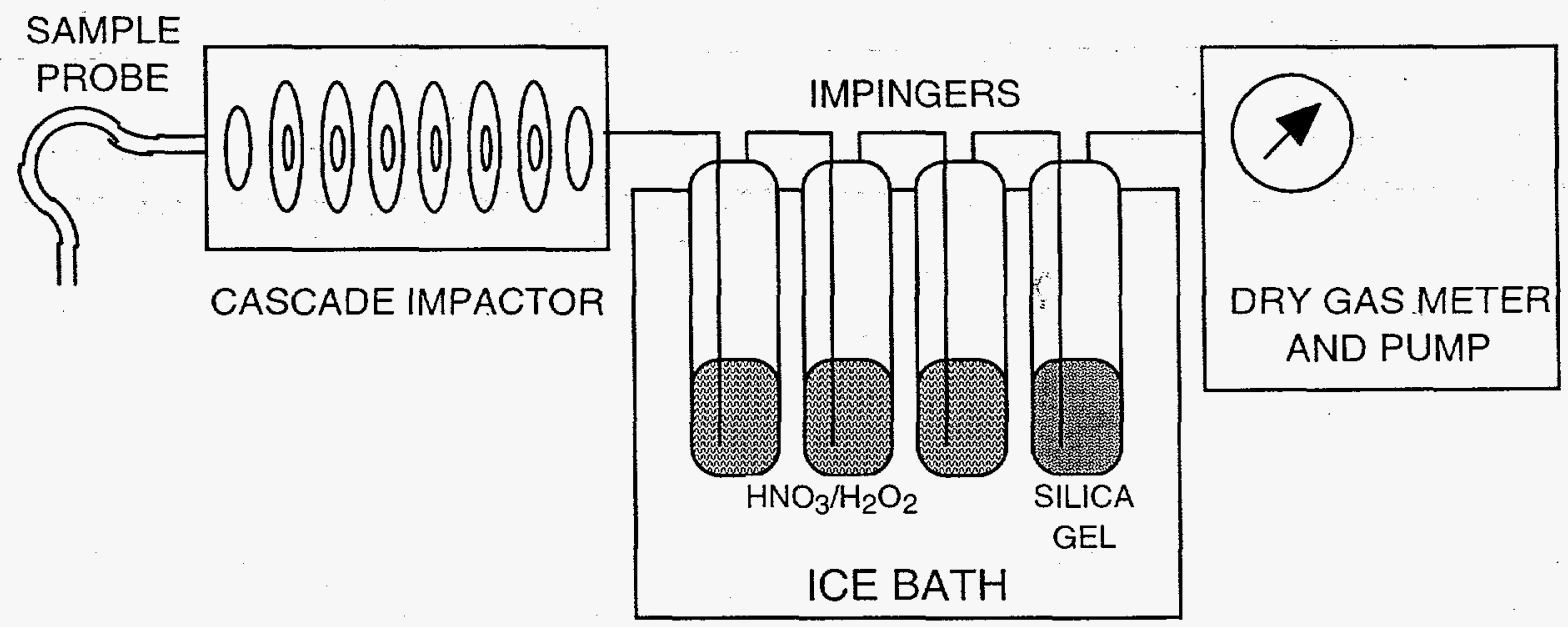

Figure 2. Offgas Sampling System 
The offgas sample from the sampling probe was conveyed through an approximately $1 / 2^{\prime \prime}$ I.D. stainless steel tube to the cascade impactor. ${ }^{1,2}$ The cascade impactor separates the incoming particles by their aerodynamic size and collects them on filter paper media. The impactor used had seven stages that separated the particles into the particle size ranges shown in Table II (cut size means particles greater than this size). The last "stage" of the impactor is an absolute filter that removes about $99+\%$ of all particles larger than 0.3-0.4um (it removes smaller particles at lower efficiency). The impactor was maintained at a temperature of approximately $300^{\circ} \mathrm{F}$ throughout sampling to avoid condensation of water.

\section{Table II. Cascade Impactor Cut Sizes}

\begin{tabular}{|cc|}
\hline Stage & Cut Size, $\mu \mathrm{m}$ \\
\hline top & $>11.1-13.2$ \\
1 & $>8.2-9.8$ \\
2 & $>3.0-3.5$ \\
3 & $>1.4-1.7$ \\
4 & $>0.80-0.97$ \\
5 & $>0.39-0.48$ \\
6 & $>0.18-0.23$ \\
Absolute & $>(0)$ \\
\hline
\end{tabular}

The sample passes out of the impactor to the EPA Method 29 sampling train. ${ }^{3}$ This sampling train normally consists of an absolute filter paper followed by a series of impingers. Since the cascade impactor has an absolute filter, the Method 29 absolute filter was removed. The impingers contained solution of $\mathrm{HNO}_{3}$ and $\mathrm{H}_{2} \mathrm{O}_{2}$ designed to scrub out volatile (i.e., non-particulate) metals. Following the impingers was a silica gel impinger and an air pump. The sample flowrate is adjusted manually using a throttling valve to maintain the desired sample flowrate. The sample flowrate is monitored by both a differential pressure orifice melter in the sample line and by calculating the flow from the dry gas meter readings. The total dry volume of sample is measured with a dry gas meter at the pump. To calculate the volume sampled at the actual conditions, this volume is adjusted for the process temperature and water content. The sample flow rate was adjusted to maintain isokinetic conditions based on process flow measurements by a pitot tube inserted in the offgas line: However, the pitot tube measurement was troublesome in that it appeared to periodically become plugged with either water or particulate and give erroneous readings. These types of problems with pitot tubes are not uncommon. Use of the process flowrates measured by the melter control system would have been more accurate and reliable and is recommended for future sampling.

The filter papers in the cascade impactor were weighed before and after sampling to determine the total particulate loading on each filter. These filters were also analyzed by dissolving completely by a microwave digestion and analyzing by Inductively Coupled Plasma- Atomic Emission Spectroscopy (ICP-AES) for elemental composition (per EPA Method 29). The impinger solutions were also analyzed by ICP-AES after preparation following EPA Method 29 procedures. The buttonhook sample line and the line to the 
cascade impactor was washed with $0.1 \mathrm{~N} \mathrm{HNO}_{3}$, acetone (Method 29) to remove any adhered particulate. This material was also analyzed by ICP-AES. The digestions and ICP-AES measurements were conducted by the SRTC Mobile Laboratory. All filter paper mass analyses, washing, and sample preparation were performed by John Harden of Clemson.

The elements determined by ICP-AES are as given below. The elements for which Method 29 is approved for regulatory measurements are given first. The second list gives additional elements that were measured.

Method 29: $\mathrm{Pb}, \mathrm{Ag}, \mathrm{As}, \mathrm{Ba}, \mathrm{Cd}, \mathrm{Cr}, \mathrm{Cu}, \mathrm{Mn}, \mathrm{Ni}, \mathrm{Se}, \mathrm{Sr}$

Additional: Al, B, Ca, Ce, Er, Eu, Fe, Gd, La, Nd, Pr, Sm

Previous Clemson tests have shown that EPA Method 29 can be used to reliably measure some elements not covered by the method. The elements $\mathrm{Si}, \mathrm{Na}$, and $\mathrm{K}$ were not measured. The filter papers used were composed of quartz $\left(\mathrm{SiO}_{2}\right)$, so reliable measurement of $\mathrm{Si}$ would be difficult. The amounts of $\mathrm{Na}$ and $\mathrm{K}$ in the melter feed were small, so measurement of these in the offgas samples would be difficult, especially considering that $\mathrm{Na}$ and $\mathrm{K}$ are relatively common contaminants.

Background estimation was performed by dissolving and analyzing several unused filter papers of both sizes (disk and annular shapes). However, the amounts of some background materials found were too low to properly adjust some of the measured values; e.g., for Run 3, where essentially no material was collected $(0.2 \mathrm{mg})$, as determined by the total sample mass, the analyses for $\mathrm{Ca}$ and $\mathrm{Al}$ indicated ten times this mass even when the background was subtracted.

The Pyrex glassware and stainless steel parts used in the sample train probably also contributed to the background amounts of several elements found in the analyses. Pyrex contains $\mathrm{Si}, \mathrm{Na}, \mathrm{B}, \mathrm{Al}, \mathrm{Ca}$ and the stainless steel contained $\mathrm{Ni}, \mathrm{Fe}$, and $\mathrm{Cr}$. The amounts of background $\mathrm{Al}$ and $\mathrm{Ca}$ found in most samples made reliable determination of these impossible, so neither of these elements are reported; the amount of $\mathrm{Al}$ expected in the offgas is small as $\mathrm{Al}_{2} \mathrm{O}_{3}$ is non-volatile, and the amount of $\mathrm{Ca}$ expected is also small since there was little in the feed. Background boron was found in all samples at levels too high to make reliable estimation of the amount collected possible. Background boron was probably also present from the ICP-AES equipment. This equipment uses borosilicate glass parts that were probably etched by the $\mathrm{HF} / \mathrm{HNO}_{3}$ dissolution mixture.

To summarize, the elements that are present in the surrogate or frit that were not measured or were not reliably measured are $\mathrm{Al}, \mathrm{B}, \mathrm{Ca}, \mathrm{Fe}, \mathrm{Na}, \mathrm{K}, \mathrm{Ni}$, and $\mathrm{Cr}$.

The accuracy of the data presented depends on three factors: the accuracy and reproducibility of the sampling techniques, the error in sample preparation, and the error in the analytical measurements. The reproducibility of the sampling methods is 
the most likely cause of error. This error would have to be determined by replicate sampling at the same process conditions. Replicate sampling was not performed.

The total particulate was determined by weighing of the filter papers. The weights were determined to the nearest $0.0001 \mathrm{~g}$. The error in this weighing appears to be about $\pm 0.0002 \mathrm{~g}$, based on weighing of filter papers before and after sampling. A number of samples showed weight losses of up to $0.0002 \mathrm{~g}$, which has been used as an indication of the error in weighing. This weight loss could be due to differences in the amount of water absorbed on the filters.

The accuracy of the elemental analyses by ICP-AES is difficult to determine without replicate analyses. Possible errors would be due to the sample preparation and the ICP-AES measurement itself. Since each filter paper was completely dissolved and analyzed, the accuracy of the sample preparation cannot be determined on actual samples. The accuracy of the ICP-AES method was not determined.

The composition of the initial glass in the melter is shown in Table III (Frit B1000). The composition of the melter feed surrogate is given in Table IV.

\section{Table III. Initial Glass Composition}

\begin{tabular}{|cc|}
\hline Oxide & Weight Percent \\
\hline $\mathrm{SiO}_{2}$ & 26.6 \\
$\mathrm{~B}_{2} \mathrm{O}_{3}$ & 3.3 \\
$\mathrm{AlO}_{2}$ & 14.1 \\
$\mathrm{LaO}_{2}$ & 16.5 \\
$\mathrm{PbO}$ & 11.0 \\
$\mathrm{Nd} 2 \mathrm{O} 3$ & 17.6 \\
$\mathrm{CeO} 2$ & 7.3 \\
$\mathrm{BaO}$ & 3.6 \\
\hline
\end{tabular}

Table IV. Melter Feed Surrogate Composition (Oxide Basis)

\begin{tabular}{||cccc||}
\hline Oxide & $\begin{array}{c}\text { Weight } \\
\text { Percent }\end{array}$ & Oxide & $\begin{array}{c}\text { Weight } \\
\text { Percent }\end{array}$ \\
\hline $\mathrm{La}_{2} \mathrm{O}_{3}$ & 11.22 & $\mathrm{Al}_{2} \mathrm{O}_{3}$ & 0.64 \\
$\mathrm{Ce}_{2} \mathrm{O}_{3}$ & 12.89 & $\mathrm{CaO}$ & 0.03 \\
$\mathrm{Pr}_{2} \mathrm{O}_{3}$ & 12.89 & $\mathrm{Cr}_{2} \mathrm{O}_{3}$ & 0.25 \\
$\mathrm{Nd}_{2} \mathrm{O}_{3}$ & 27.32 & $\mathrm{Fe}_{2} \mathrm{O}_{3}$ & 2.20 \\
$\mathrm{Sm}_{2} \mathrm{O}_{3}$ & 6.33 & $\mathrm{MnO}$ & 8.43 \\
$\mathrm{Eu}_{2} \mathrm{O}_{3}$ & 1.25 & $\mathrm{Na}$ & 0.28 \\
$\mathrm{Gd}_{2} \mathrm{O}_{3}$ & 3.22 & $\mathrm{~K} O$ & 0.08 \\
$\mathrm{Er}_{2} \mathrm{O}_{3}$ & 12.89 & $\mathrm{NiO}$ & 0.09 \\
\hline
\end{tabular}




\section{RESULTS AND DISCUSSION}

The process was sampled from the melter offgas line downstream of the film cooler and control air addition ports and from the offgas line between the condensate tank and the HEME. Table V shows the locations and conditions used for the six tests performed.

Table V. Test Summary and Process Conditions

\begin{tabular}{|c|c|c|c|c|c|c|c|}
\hline Location & & $\begin{array}{l}\text { Run } 1 \\
\text { Melter }\end{array}$ & $\begin{array}{l}\text { Run } 2 \\
\text { HEME }\end{array}$ & $\begin{array}{l}\text { Run } 3 \\
\text { Melter }\end{array}$ & $\begin{array}{l}\text { Run } 4 \\
\text { Melter }\end{array}$ & $\begin{array}{l}\text { Run } 5 \\
\text { Melter }\end{array}$ & $\begin{array}{l}\text { Run } 6 \\
\text { HEME } \\
\end{array}$ \\
\hline Melter Temperature & ${ }^{\circ} \mathrm{C}$ & 1450 & 1450 & 1150 & 1450 & 1450 & 1450 \\
\hline Film Cooler Steam & & No & No & No & No & Yes & Yes \\
\hline Feeding & & No & No & No & Yes & No & No \\
\hline Temperature at Sample & ${ }^{\circ} \mathrm{C}$ & 100 & 35 & 77 & 103 & 99 & 48 \\
\hline Saturation Temp. at Melter & ${ }^{\circ} \mathrm{C}$ & NA & 35 & NA & 31 & 71 & 71 \\
\hline Process Flowrate & acfm & 61.5 & 50.2 & 53.9 & 55.0 & 69.0 & 60.7 \\
\hline Total Sample (wet) & $\operatorname{scf}$ & 24.0 & 43.5 & 40.4 & 41.2 & 35.3 & 40.9 \\
\hline Sampling Time & $\min$ & 29 & 60 & 62 & 59 & 39 & 43 \\
\hline $\begin{array}{r}\text { Sample Flowrate (wet) } \\
\text { (at nozzle) }\end{array}$ & acfm & 1.13 & 0.82 & 0.84 & 0.96 & 1.23 & 1.12 \\
\hline Process Velocity & $\mathrm{ft} / \mathrm{sec}$ & 44.0 & 38.0 & 38.6 & 39.4 & 49.3 & 33.6 \\
\hline Sample Velocity & $\mathrm{ft} / \mathrm{sec}$ & 35.4 & 25.6 & 26.1 & 30.0 & 38.6 & 35.0 \\
\hline$\%$ Isokinetic & & 81 & 67 & 68 & 76 & 78 & 104 \\
\hline $\begin{array}{r}\text { Total Offgas Flow } \\
\text { (Measured) }\end{array}$ & $\mathrm{lb} / \mathrm{hr}$ & 219 & 216 & 210 & 191 & 194 & 193 \\
\hline $\begin{array}{r}\text { Total Offgas Flow @ HEPA } \\
\text { (Calculated) }\end{array}$ & $\mathrm{lb} / \mathrm{hr}$ & 226 & 223 & 211 & 192 & 180 & 184 \\
\hline $\begin{array}{r}\text { Total Offgas Flow @ HEPA } \\
\text { (Calculated-MEB *) }\end{array}$ & $\mathrm{lb} / \mathrm{hr}$ & 240 & 240 & 220 & 203 & 195 & 195 \\
\hline $\begin{array}{r}\text { Offgas Flow at Melter } \\
\text { (Calculated) }\end{array}$ & $\mathrm{lb} / \mathrm{hr}$ & 218 & 216 & 203 & 185 & 215 & 219 \\
\hline Film Cooler Air & $\mathrm{lb} / \mathrm{hr}$ & 131 & 131 & 132 & 132 & 87 & 86 \\
\hline Control Air & $\mathrm{lb} / \mathrm{hr}$ & 87 & 85 & 71 & 53 & 79 & 83 \\
\hline FC Steam & $\mathrm{lb} / \mathrm{hr}$ & 0 & 0 & 0 & 0 & 50 & 50 \\
\hline Surrogate Feedrate & liter/hr & 0 & 0 & 0 & 2.5 & 0 & 0 \\
\hline Frit Feedrate & $\mathrm{kg} / \mathrm{hr}$ & 0 & 0 & 0 & 0.5 & 0 & 0 \\
\hline HNO3 Generated & $\mathrm{lb} / \mathrm{hr}$ & 0 & 0 & 0 & 0.97 & 0 & 0 \\
\hline NO Generated & $\mathrm{lb} / \mathrm{hr}$ & 0 & 0 & 0 & 0.34 & 0 & 0 \\
\hline Water Generated & $\mathrm{lb} / \mathrm{hr}$ & 0 & 0 & 0 & 5.2 & 0 & 0 \\
\hline
\end{tabular}

* Calculated by more detailed material and energy balance (see Appendix B). acfm $=$ actual cubic feet per minute, scf $=$ standard cubic feet

For Runs 1,3, and 5, the offgas flow at the melter was assumed to be the sum of the film cooler air, film cooler steam, and control air flows. The air inleakage was assumed to be negligible. This flow was calculated since it was not directly measured by the process flow monitoring system. 
For Runs 2 and 6, the offgas flow at the HEME was calculated assuming that the gas leaving the HEME was saturated with water at the temperature of the condensate tank. The offgas flow meter at the HEPA is not necessarily accurate for the actual flow conditions since it was not calibrated for an air/water mixture.

For Run 4, the melter offgas was calculated to be the sum of the film cooler air and steam, the control air, the water evaporated from the feed, the $\mathrm{HNO}_{3}$ evaporated from the feed, and the NO evolved from feed nitrate decomposition (all nitrates were assumed to decompose to NO).

A more detailed material and energy balance was performed by A. S. Choi (see Appendix B) and gave calculated offgas flows that are $4.1-7.7 \%$ higher than those calculated in this analysis.

It was assumed that all of the particulate deposited in the sampling system was in the form of oxides, except for Run 4. The elemental analyses were used to calculate the amount of oxides, where the oxide forms assumed were the same as those in the glass. For Run 4, it was determined that much of the particulate was due to feed entrainment, so the feed elements were assumed to be present as nitrates rather than oxides; the frit components were still assumed to be oxides. The assumption of entrainment of nitrates rather than emission as oxides improved the calculated mass/measured mass ratio.

Table $\mathrm{V}$ also shows the percent isokinetic for each of the samples taken (percent isokinetic is a measure of the relative velocity in the sampling tube to the velocity in the process). This value is an average for each run; the actual percent isokinetic most likely varied around the stated values. For a particulate sample to accurately represent the particle size distribution in the actual process, the percent isokinetic should be between $90-110 \%$. Only Run 6 falls within this range. However, for all runs except Run 4, the lack of truly isokinetic sampling is not significant, since the importance of maintaining isokinetic conditions diminishes as the particle size decreases. At particle sizes less than about $2 \mu \mathrm{m}$, lack of isokinetic conditions does not bias the sample. In Run 4 , where most of the particles in the sample were in the 1-10 $\mu \mathrm{m}$ and greater range, the $76 \%$ isokinetic value indicates that the sample velocity was too low. Too low a sample velocity results in a higher measured concentration of particulate than actual and biases the size distribution towards larger particles. Therefore, the true particle size distribution probably should have a smaller percentage of particles at sizes above 2-3 $\mu \mathrm{m}$.

The method used to control the sampling rate was measurement of the process velocity by a pitot tube inserted into the process stream. ${ }^{4}$ As mentioned in the Experimental section, the pitot tube periodically gave erroneous readings. For future work, the calculated "Total Offgas Flow @ HEPA" (Table V) should be used to set the sampling rate. This quantity can easily be calculated with a simple spreadsheet and process inputs from the melter control system.

The data in Table VI indicates that about 40 to $60 \%$ of the materials collected on the filter papers for each run were not accounted for by the elemental analyses of the filter 
papers. Some of the unmeasured mass in these data could be accounted for if the amounts of the unmeasured and unreliably measured elements $(\mathrm{Al}, \mathrm{B}, \mathrm{Ca}, \mathrm{Fe}, \mathrm{Na}, \mathrm{K}, \mathrm{Ni}$, and $\mathrm{Cr}$ ) were added in.

\section{Table VI. Calculated Mass/ Measured Mass Ratio}

\begin{tabular}{|cc|}
\hline Run & Ratio (\%) \\
\hline 1 & 64 \\
2 & 61 \\
4 & 45 \\
5 & 44 \\
6 & 37 \\
\hline
\end{tabular}

The results of each test will be discussed next. Then, the results of the tests will be compared.

\section{Run 1 - Melter Location - Melter Idling @ $1450^{\circ} \mathrm{C}$}

The results for Run 1 show that virtually all of the particulate collected is in the sub-micron range and that about $63 \%$ of the particulate was $\mathrm{PbO}$. Figure 3 shows the particle size distribution for the total mass measured. For this run, only the absolute filter at the end of the cascade impactor train was analyzed for elemental composition. Also note that this filter paper was inadvertently analyzed together with the sample line sample. The elemental analysis of these combined samples showed the presence of only $\mathrm{Pb}$.

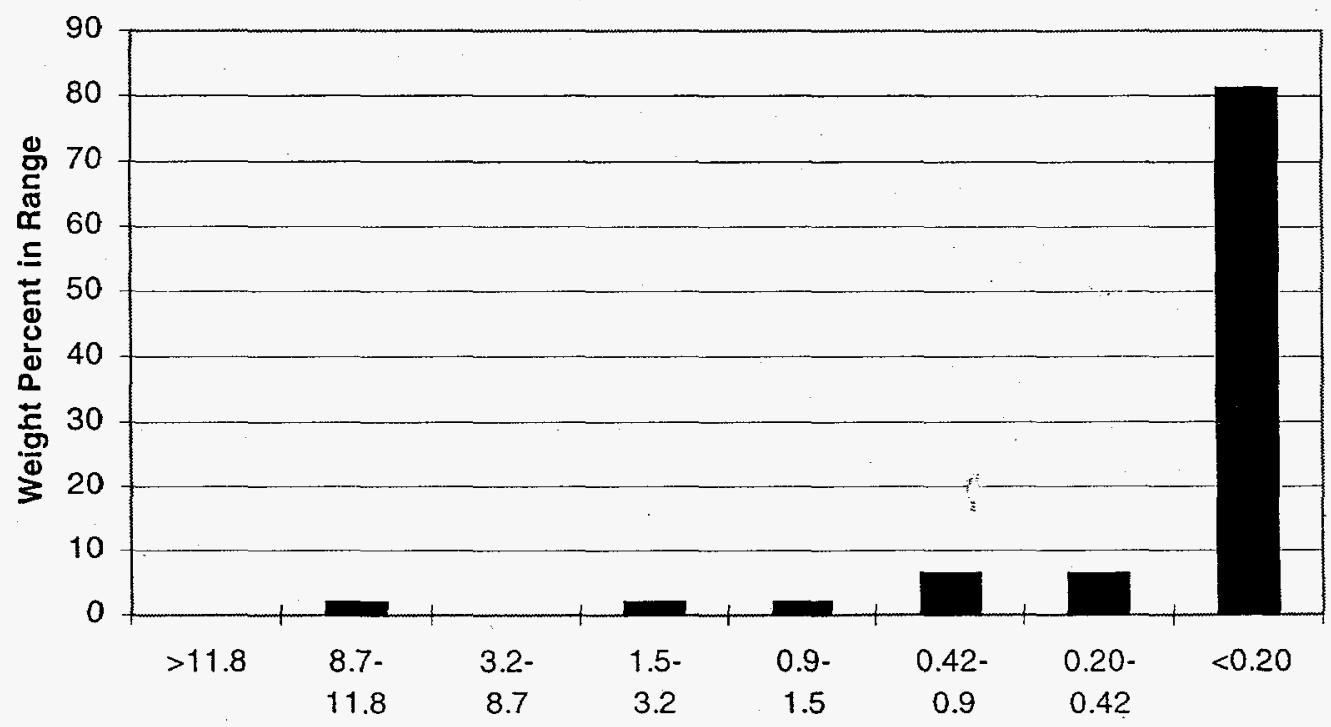

Aerodynamic Particle Diameter, $d_{50}(\mu \mathrm{m})$

Figure 3. Total Particle Size Distribution for Run 1.

The total particulate and PbO concentrations in the offgas for Run 1 were $0.200 \mathrm{mg} / \mathrm{dscf}$ and $0.125 \mathrm{mg} / \mathrm{dscf}$, respectively. The offgas contained no water, so concentrations in 
$\mathrm{mg} /$ wet scf do not apply. The total particulate concentration is based on the total particulate weight measured on the filter papers; it does not contain the weight of particulate deposited on the sample line or any amount accumulated in the impingers, so the actual total particulate concentration may be higher than reported. Moreover, any particulate accumulated on the film cooler and the offgas line up to the sampling point was not be accounted for either; material deposited prior to the sample system is not accounted for in any of the runs. The $\mathrm{PbO}$ concentrations include the elemental $\mathrm{Pb}$ detected in the sample line, impactor filter papers, and the impingers. The $\mathrm{PbO}$ mass was calculated from the analyzed total mass of $\mathrm{Pb}$.

\section{Run 2-HEME Location - Melter Idling @ $1450^{\circ} \mathrm{C}$}

Run 2 results are very similar to those for Run 1. Greater than $75 \mathrm{wt} \%$ of the total particulate was found to be less than $0.22 \mu \mathrm{m}$. PbO accounted for about $56 \%$ of the total. For this run, the absolute filter paper and the sample line samples were again combined. Figure 4 shows the total particle size distribution. The particulate concentration was $0.170 \mathrm{mg} /$ wet scf $(0.180 \mathrm{mg} / \mathrm{dscf})$ and the $\mathrm{PbO}$ concentration was $0.104 \mathrm{mg} /$ wet scf (0.110 mg/dscf).

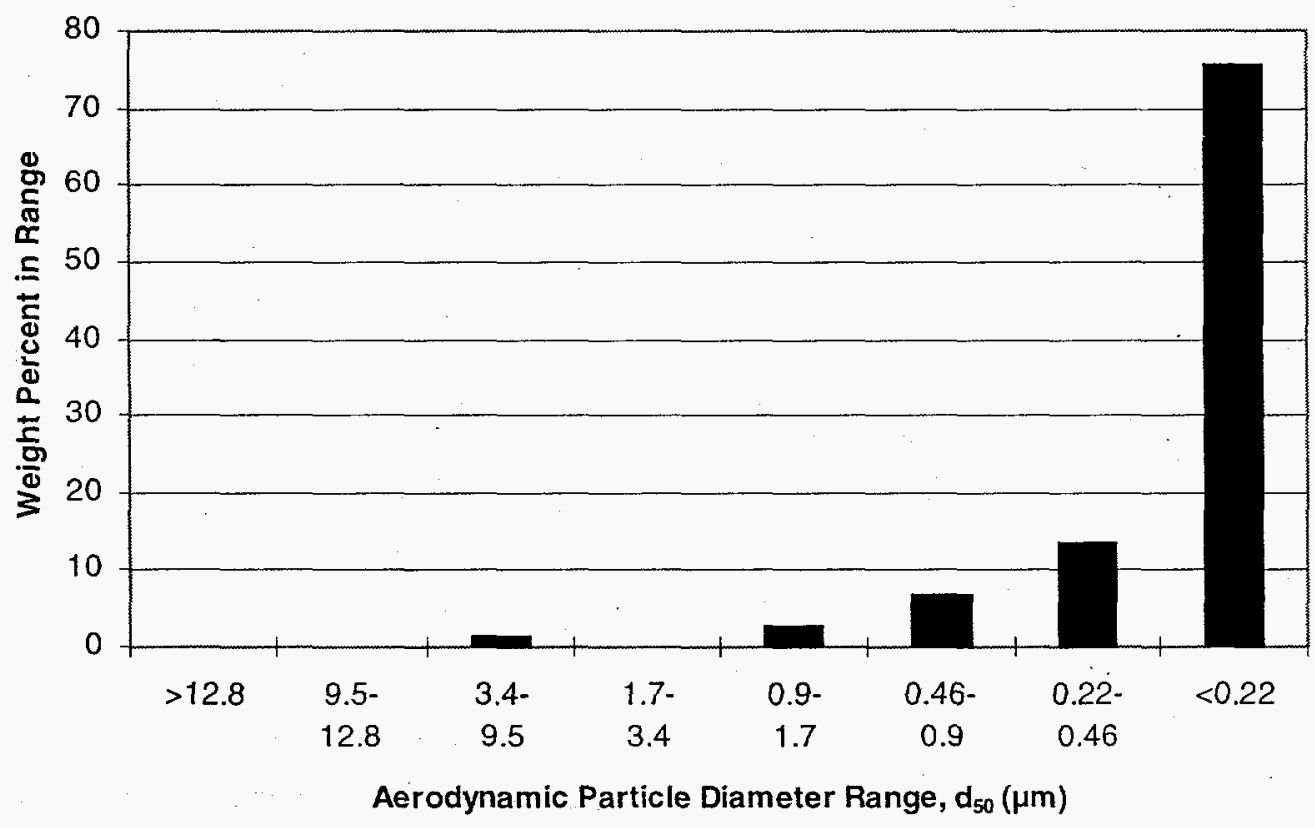

Figure 4. Total Particle Size Distribution for Run 2.

\section{Run 3 - Melter Location - Melter Idling @ $1150^{\circ} \mathrm{C}$}

Very little particulate was collected in this run, where the melter temperature was $1150^{\circ} \mathrm{C}$ at idle. The total particulate collected was only $0.0002 \mathrm{~g}$, which was barely detectable and is on the order of the analytical error (accuracy of weighing a filter paper was about $\pm 0.0002 \mathrm{~g}$ ), so the actual amount collected might be considered to be zero. No $\mathrm{Pb}$ was detected in any of the filter paper samples; detection of $\mathrm{B}$ was inconclusive due to high background $\mathrm{B}$. The detection limit for $\mathrm{Pb}$ on the filter papers was around $22 \mu \mathrm{g}$. If the entire $0.0002 \mathrm{~g}$ of total particulate were $\mathrm{PbO}$, the $\mathrm{Pb}$ analysis would have been 
about $186 \mu \mathrm{g}$ detected. The lack of detected $\mathrm{Pb}$ supports the possibility that the actual total emission was essentially zero. The impingers and sample line were not analyzed. All of the particulate was detected on the absolute filter, and was therefore less than $0.24 \mu \mathrm{m}$. The concentration of total particulate in the offgas is estimated to be 0.005 $\mathrm{mg} /$ dry scf or less and the evolution rate was $0.21 \mathrm{mg} / \mathrm{min}$ or less. The ratio of particulate evolution at idling at $1450^{\circ} \mathrm{C}$ to that at $1150^{\circ} \mathrm{C}$, which is an indication of relative volatility, was about 43 or greater.

\section{Run 4 - Melter Location - Melter Feeding @ $1450^{\circ} \mathrm{C}$}

A much more significant amount of particulate was collected during this run in which the melter was fed with surrogate and frit. Figure 5 shows the total particle size distribution based on the filter paper mass measurements:

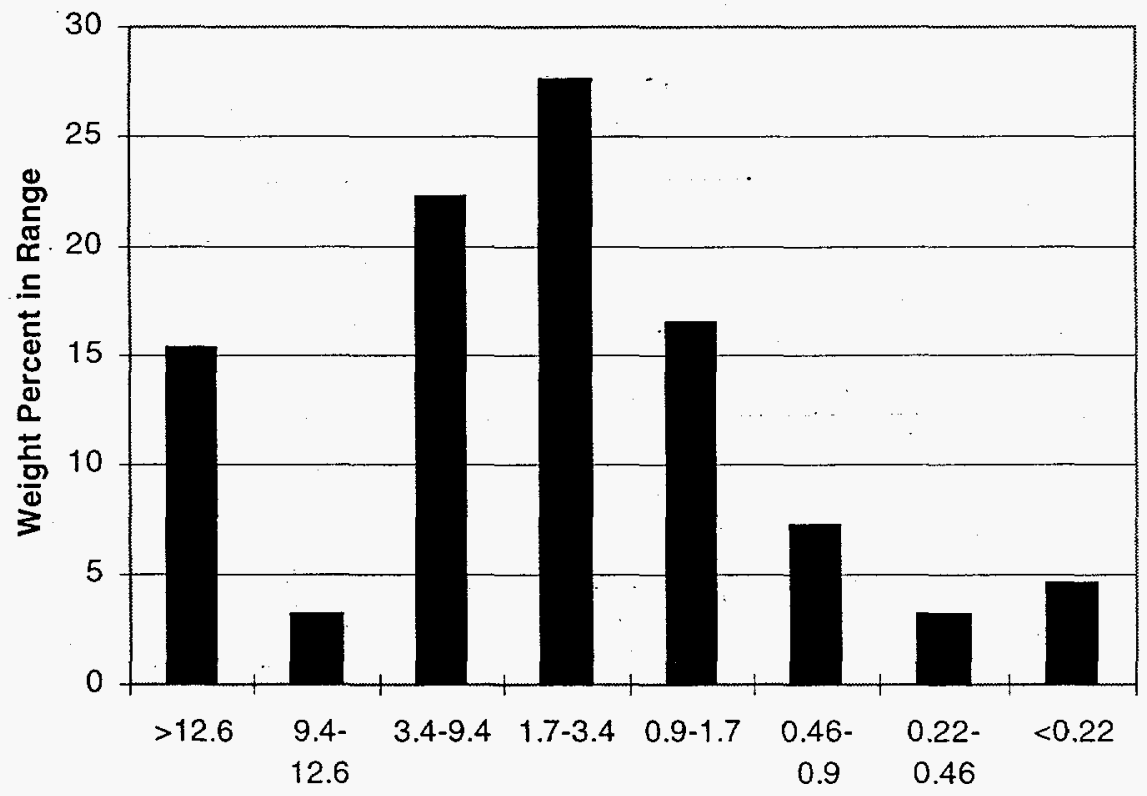

Aerodynamic Particle Diameter, $d_{50}(\mu \mathrm{m})$

Figure 5. Total Particle Size Distribution for Run 4.

For this run, $85 \mathrm{wt} \%$ of the particulate was found to be larger than $1 \mu \mathrm{m}$. The fraction smaller than $1 \mu \mathrm{m}$ consisted of about $49 \mathrm{wt} \% \mathrm{PbO}$ and $44 \mathrm{wt} \%$ lanthanide oxides, and 7 $w t \%$ others (of the elements measured). The odd distribution at the two large sizes is probably real and is due to some particles that were lodged in the jet plate between stage 1 and 2 . These particles were removed from the jet plate and weighed with stage 1 , but probably should have been put with stage 2 . Figure 6 shows the total particle size distribution for the oxides/nitrates calculated from the elemental analyses. This distribution is very similar to Figure 5 except for the two largest size fractions. The difference at these fractions could be due to the presence of $\mathrm{Si}$ in the largest fraction; $\mathrm{Si}$ is expected to be present only from entrainment of glass and entrainment of glass generally results in large particles. Therefore, the calculated total mass at $>12.6 \mu \mathrm{m}$ including $\mathrm{SiO}_{2}$ would be greater than that shown in Figure 6. The oxide/nitrate particle size distribution would be identical to the total particulate distribution if all elements 
were measured and were measured accurately. The only element detected in the impingers was boron, but measurement of this element was unreliable.

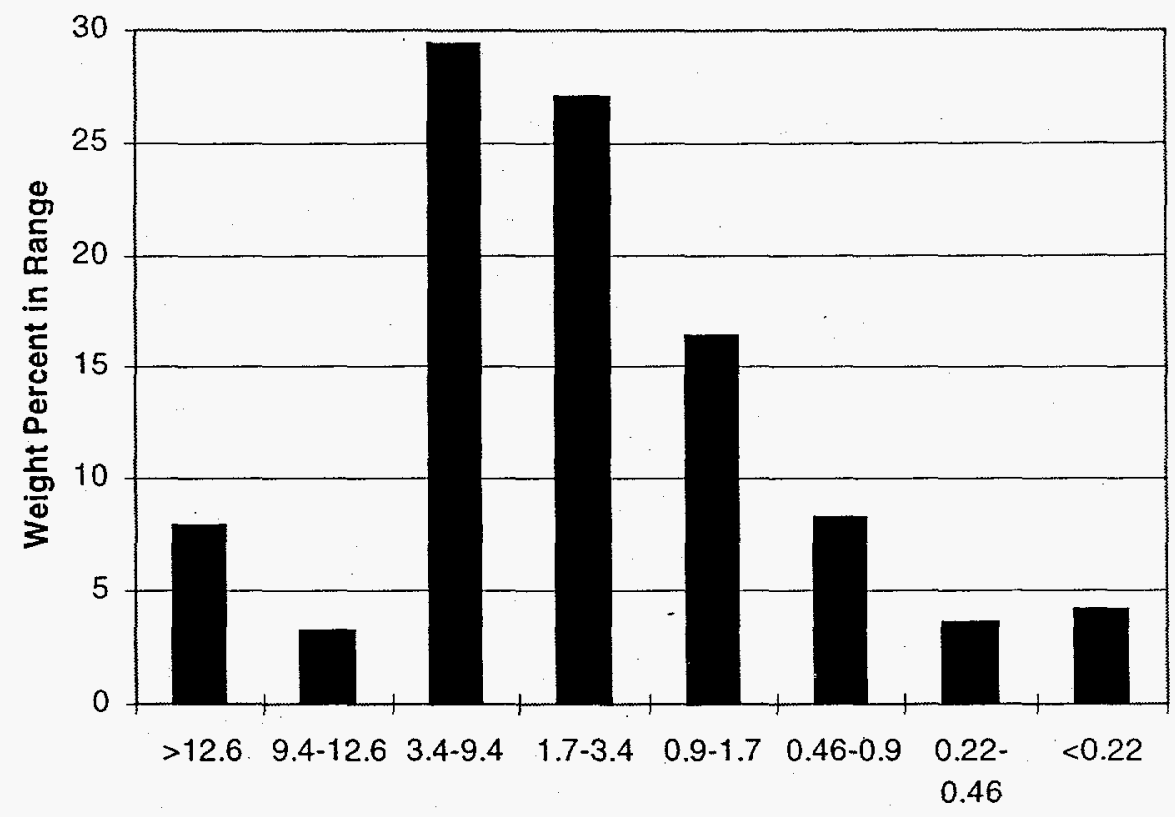

Aerodynamic Particle Diameter, $d_{50}(\mu \mathrm{m})$

Figure 6. Oxide/Nitrate Particle Size Distribution for Run 4 (Excluding Impingers).

The weight percent of each oxide/nitrate in the combined filter paper + impingers + sample line is compared with the distribution of the nitrates in the surrogate feed in Figure 7. (The sample line weight is the material collected on the sample line entering the cascade impactor.) Except for $\mathrm{Pb}$, the distributions are very similar. Figure 8 shows this same comparison, with the $\mathrm{Pb}$ subtracted from the sample oxide/nitrate weight.

Figures 7 and 8 clearly show that the total material collected on the filter papers was essentially entrained surrogate feed plus the volatile glass (frit) component $\mathrm{Pb}$. This behavior was expected.

The distribution of the oxides/nitrates by element for the sample line deposits, and the filter papers + impingers is given in Figure 9. All of the lanthanides are most prevalent in the sample line, while $\mathrm{Ba}, \mathrm{Cr}, \mathrm{Fe}$, and $\mathrm{Mn}$ were about equal in the sample line and filter papers + impingers. The $\mathrm{Pb}$ was found mostly in the filter papers. 


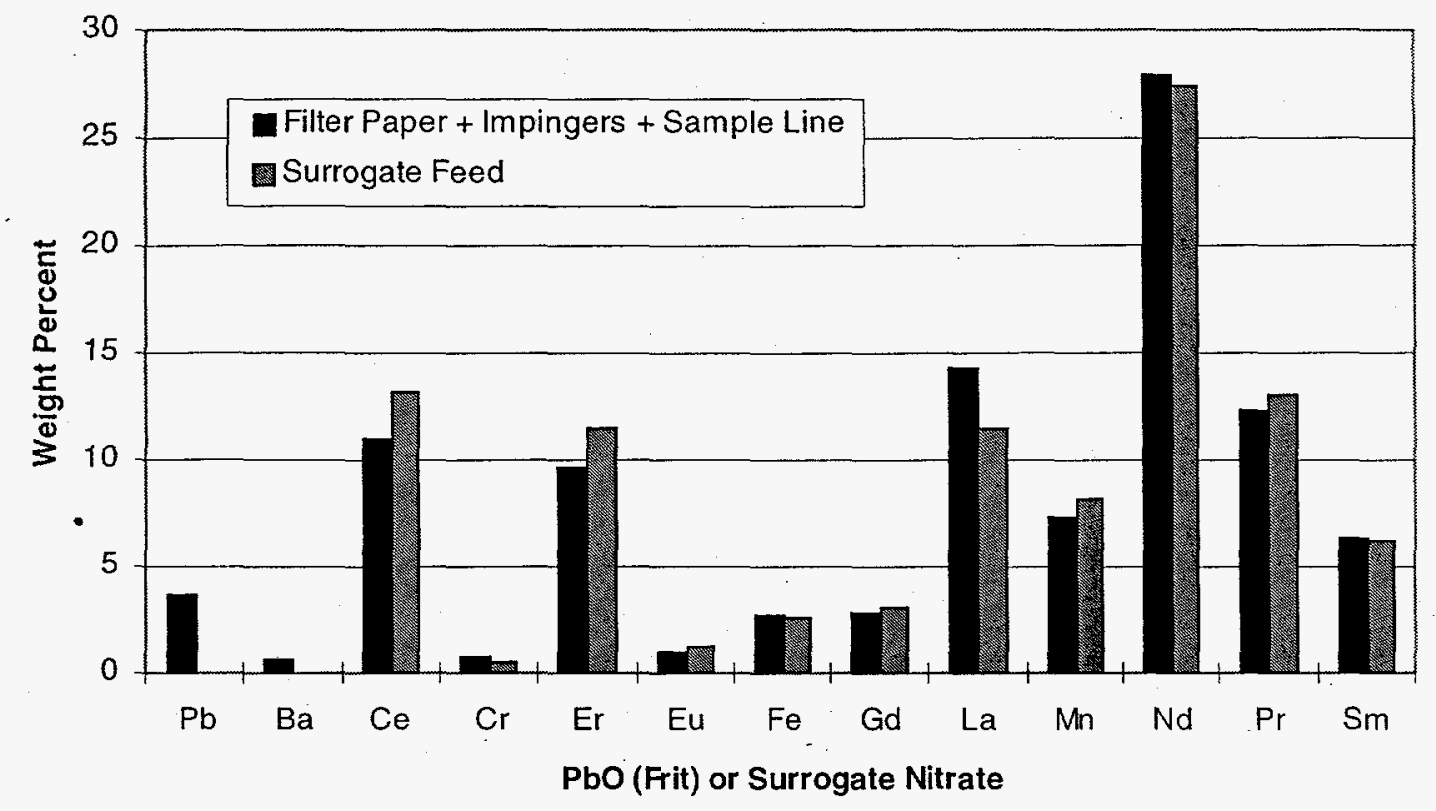

Figure 7. Run 4 Comparison of Sample and Feed Oxide/Nitrate Distribution

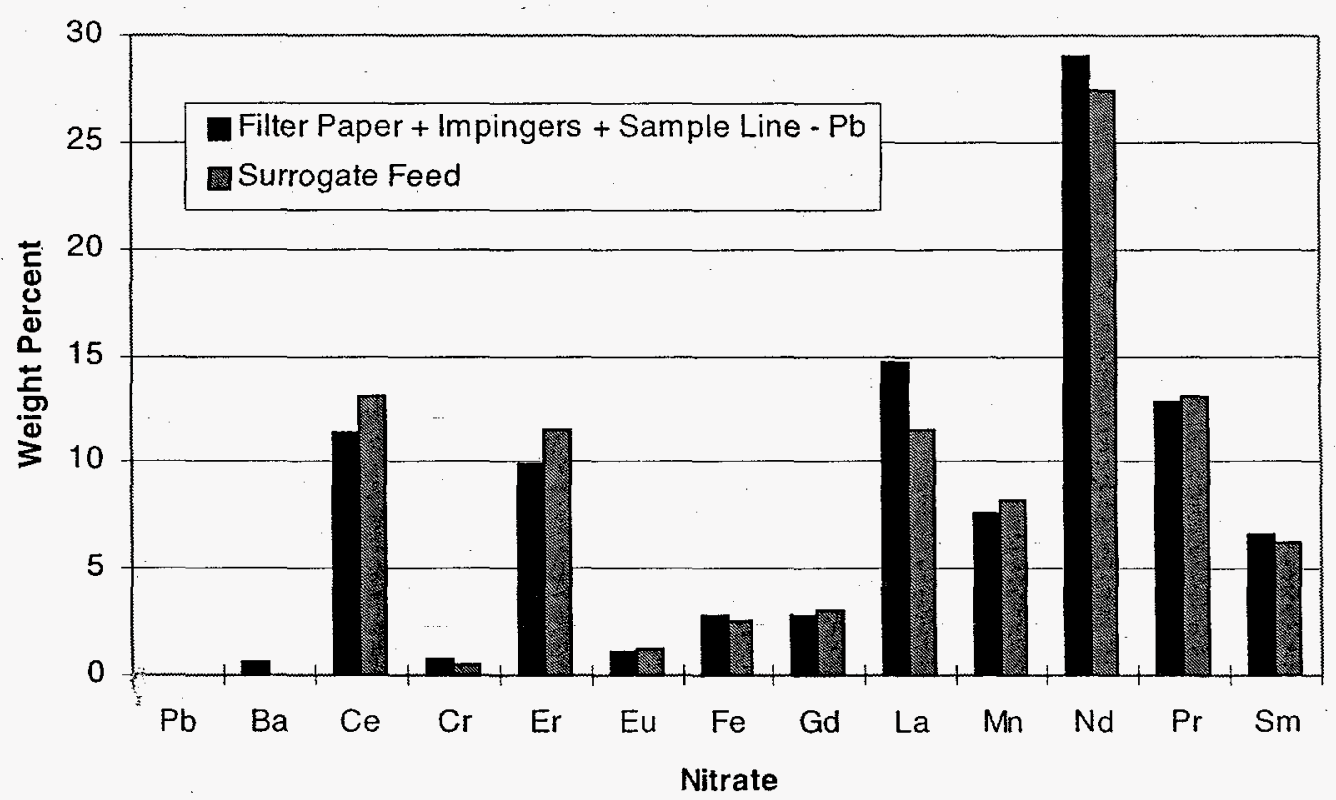

Figure 8. Run 4 Sample and Feed Oxide/Nitrate Distribution (excluding $\mathrm{Pb}$ ) 


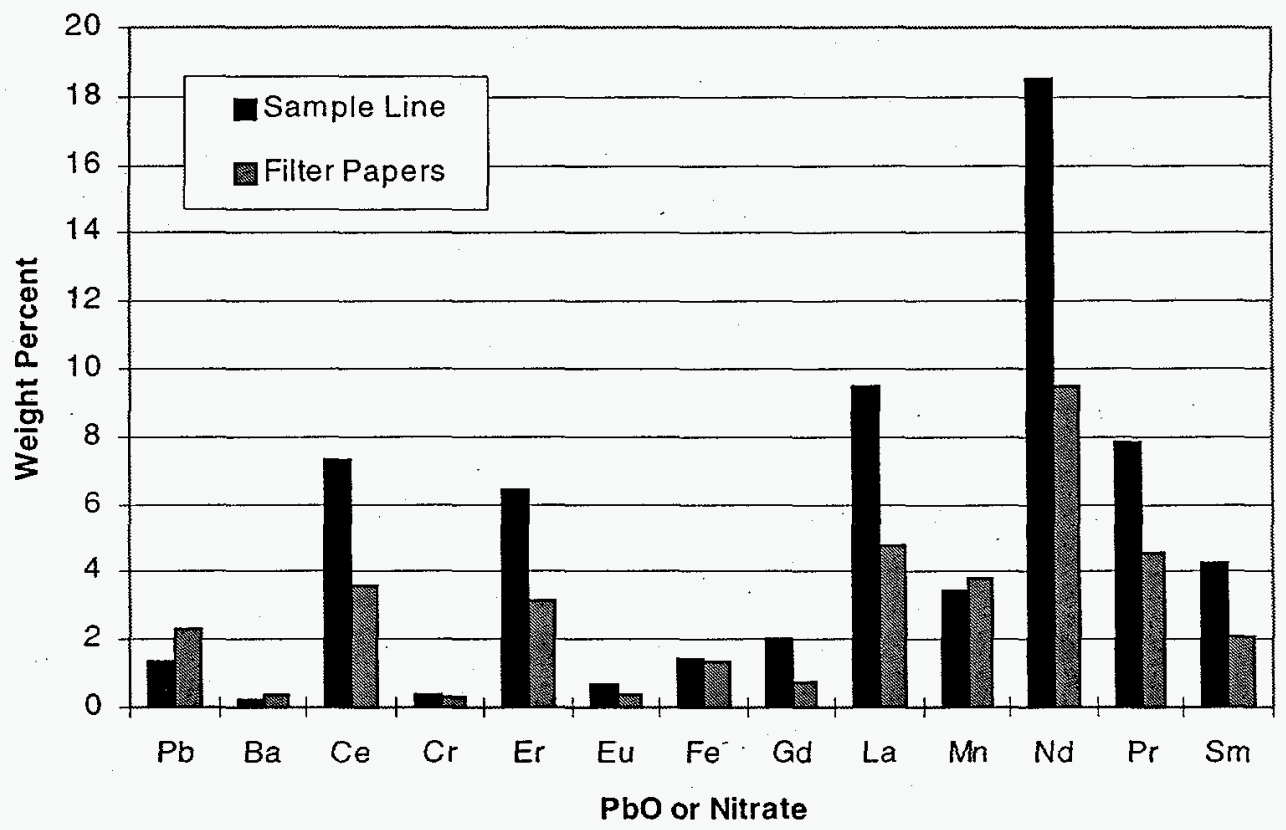

Figure 9. Run 4 Distribution of Oxides/Nitrates by Element in the Sampling Train

Table VII shows the concentrations of the surrogate feed + frit $\mathrm{PbO}$ and offgas samples, and the offgas emissions rates for Run 4 . The element with the highest emission rate was $\mathrm{Nd}$. Next highest were $\mathrm{Ce}, \mathrm{Er}, \mathrm{La}$, and $\mathrm{Pr}$. The emission rate of $\mathrm{Pb}$ was lower than most of the feed components, indicating that feed entrainment was the most significant contributor to the offgas emissions and that the presence of the cold cap inhibited the volatility of $\mathrm{Pb}$, as expected. Distribution of the oxides/nitrates versus particle size graphs are given in Appendix A.

The total particulate concentration based on the filter papers only was $1.99 \mathrm{mg} / \mathrm{dscf}$ $(1.90 \mathrm{mg} /$ wet scf). The total particulate concentration based on the elemental analyses of the combined sample line, filter papers, impingers was $2.32 \mathrm{mg} / \mathrm{dscf}(2.42 \mathrm{mg} /$ wet scf). The $\mathrm{PbO}$ concentration was $0.0878 \mathrm{mg} / \mathrm{dscf}(0.0840 \mathrm{mg} /$ wet scf).

\section{Run 5 - Melter Location-Melter Idling@ $1450^{\circ} \mathrm{C}$ - Film Cooler Steam}

The particle size distribution for this run is shown in Figure 10. These data show that most of the mass of the particles was greater than about $11 \mu \mathrm{m}$, which would not be expected during idling; the distribution was expected to be similar to Run 1 . This run was performed soon after Run 4, in which the melter had been fed. It appears that the injection of steam to the film cooler "cleaned" the film cooler and removed some of the deposited material. Inspection of the film cooler and offgas line after feeding in previous runs has shown deposition of solids on both the film cooler and offgas line. Inspection of the film cooler and offgas line after the current tests showed that virtually all of the deposits had been removed during operation with steam. This result is consistent with visual observations of the system after previous inspections. 
Table VII. Run 4 Feed + Frit Pb, Offgas Compositions, Offgas Emissions Rates

\begin{tabular}{|lcccc||}
\hline & $\begin{array}{c}\text { Surrogate } \\
+\mathrm{Pb} \\
(\mathrm{wt} \%)\end{array}$ & $\begin{array}{c}\text { Offgas } \\
\text { Solids } \\
\text { (wt \%) }\end{array}$ & $\begin{array}{c}\text { Offgas } \\
\text { (mg/dscf) }\end{array}$ & $\begin{array}{c}\text { Offgas } \\
\text { (mg/wet scf) }\end{array}$ \\
\hline $\mathrm{La}\left(\mathrm{NO}_{3}\right)_{3}$ & 9.72 & 14.30 & 0.330 & 0.345 \\
$\mathrm{Ce}\left(\mathrm{NO}_{3}\right)_{3}$ & 11.12 & 10.98 & 0.253 & 0.265 \\
$\mathrm{Pr}\left(\mathrm{NO}_{3}\right)_{3}$ & 11.09 & 12.41 & 0.286 & 0.299 \\
$\mathrm{Nd}\left(\mathrm{NO}_{3}\right)_{3}$ & 23.21 & 28.14 & 0.649 & 0.678 \\
$\mathrm{Sm}\left(\mathrm{NO}_{3}\right)_{3}$ & 5.27 & 6.37 & 0.147 & 0.154 \\
$\mathrm{Eu}\left(\mathrm{NO}_{3}\right)_{3}$ & 1.03 & 1.03 & 0.0237 & 0.0248 \\
$\mathrm{Gd}\left(\mathrm{NO}_{3}\right)_{3}$ & 2.61 & 2.78 & 0.0641 & 0.0670 \\
$\mathrm{Er}\left(\mathrm{NO}_{3}\right)_{3}$ & 9.74 & 9.66 & 0.223 & 0.233 \\
$\mathrm{Al}\left(\mathrm{NO}_{3}\right)_{3}$ & 0.87 & & & \\
$\mathrm{Ca}\left(\mathrm{NO}_{3}\right)_{2}$ & 0.03 & & & 0.0164 \\
$\mathrm{Cr}\left(\mathrm{NO}_{3}\right)_{3}$ & 0.42 & 0.68 & 0.0157 & 0.0654 \\
$\mathrm{Fe}\left(\mathrm{NO}_{3}\right)_{3}$ & 2.17 & 2.71 & 0.0626 & 0.176 \\
$\mathrm{Mn}\left(\mathrm{NO}_{3}\right)_{2}$ & 6.93 & 7.30 & 0.168 & \\
$\mathrm{Ni}\left(\mathrm{NO}_{3}\right)_{2}$ & 0.07 & & & 0.0878 \\
$\mathrm{PbO}$ & 15.71 & 3.64 & 0.0840 & 0.0138 \\
$\mathrm{BaO}$ & & 0.57 & 0.0132 & 2.42 \\
\hline $\mathrm{Total}$ & & & 2.32 & \\
\hline
\end{tabular}

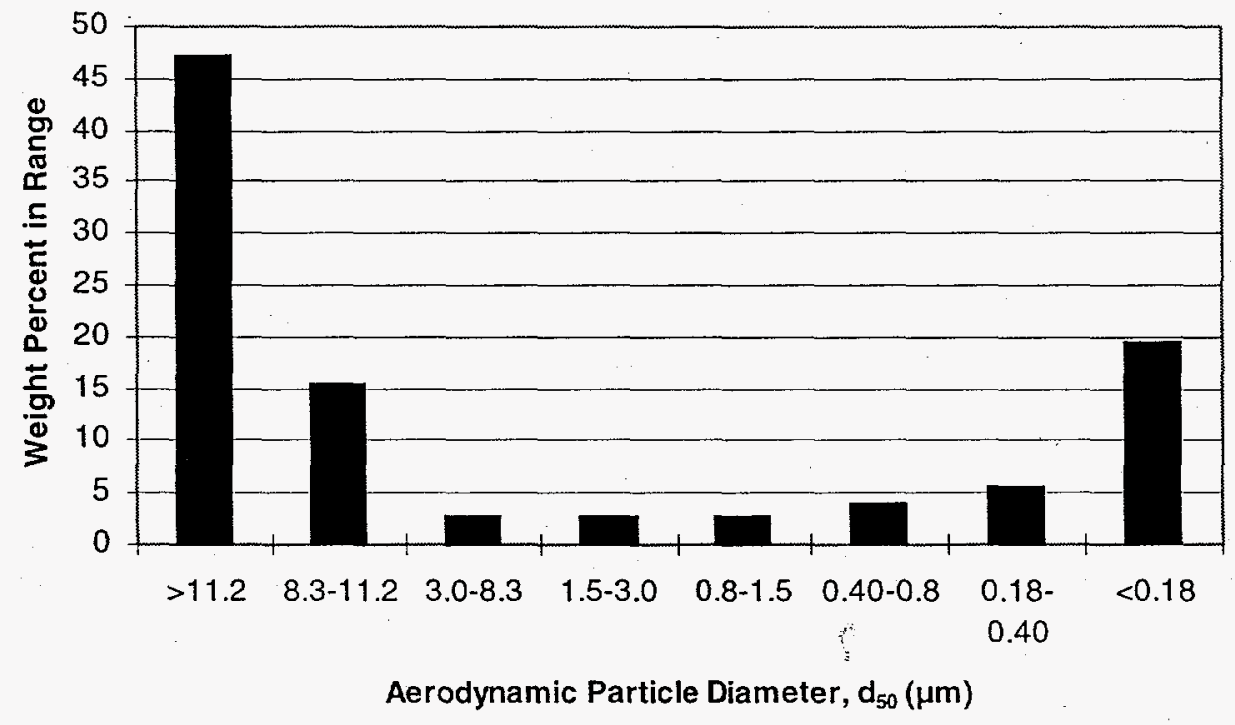

Figure 10. Total Particle Size Distribution for Run 5

The elemental analysis of the impactor samples shows that the top filter sample $(>11.2$ $\mu \mathrm{m})$ contains lanthanides ( $\mathrm{Er}, \mathrm{La}, \mathrm{Nd}, \mathrm{Pr}, \mathrm{Sm}$ ) in proportions similar to the feed and also some $\mathrm{Pb}$. The only other stages on which oxides were detected were those $<0.8 \mu \mathrm{m}$; however, some oxides must have been present on the 8.3-11.2 $\mu \mathrm{m}$ stage. If the presence of the "cleaned" material on the first two stages is ignored, the distribution looks similar to Run 1. The oxide distribution is shown in Figure 11. The total particulate 
concentration was $0.302 \mathrm{mg} / \mathrm{dscf}(0.204 \mathrm{mg} /$ wet $\mathrm{scf})$ and the $\mathrm{PbO}$ was $0.049 \mathrm{mg} / \mathrm{dscf}$ $(0.033 \mathrm{mg} /$ wet scf). These values exclude the material on the first two filter papers.

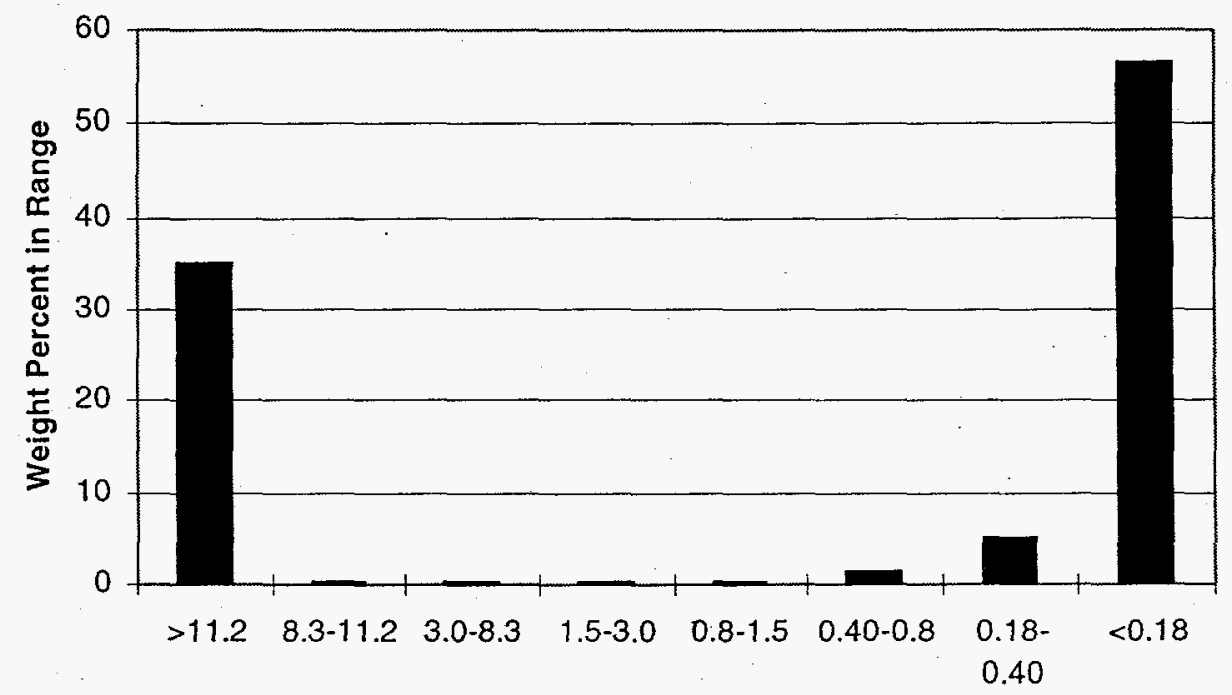

Aerodynamic Particle Diameter, $d_{50}(\mu \mathrm{m})$

Figure 11. Oxide/Nitrate Particle Size Distribution for Run 5

\section{Run 6 - HEME Location - Melter Idling @ $1450^{\circ} \mathrm{C}$ - Film Cooler Steam}

The total particle size distribution for this run is shown in Figure 12. As in the other runs at idling, most of the particulate collected was in the $<0.2 \mu \mathrm{m}$ (bottom) stage. Some particulate was detected at $>11.1 \mu \mathrm{m}$ and at $0.8-2.9 \mu \mathrm{m}$ by weighing, but essentially none was detected by the elemental analysis. Figure 13 shows the distribution for the oxides.

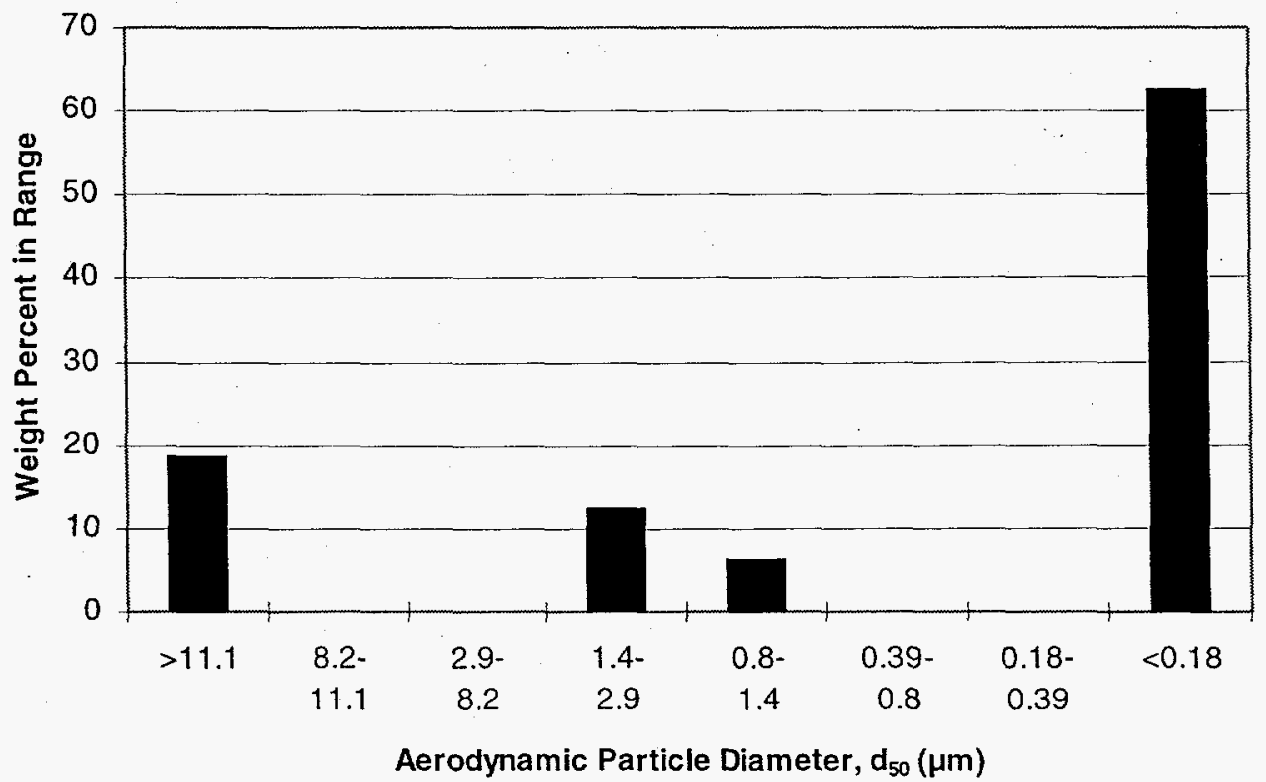

Figure 12. Total Particle Size Distribution for Run 6 


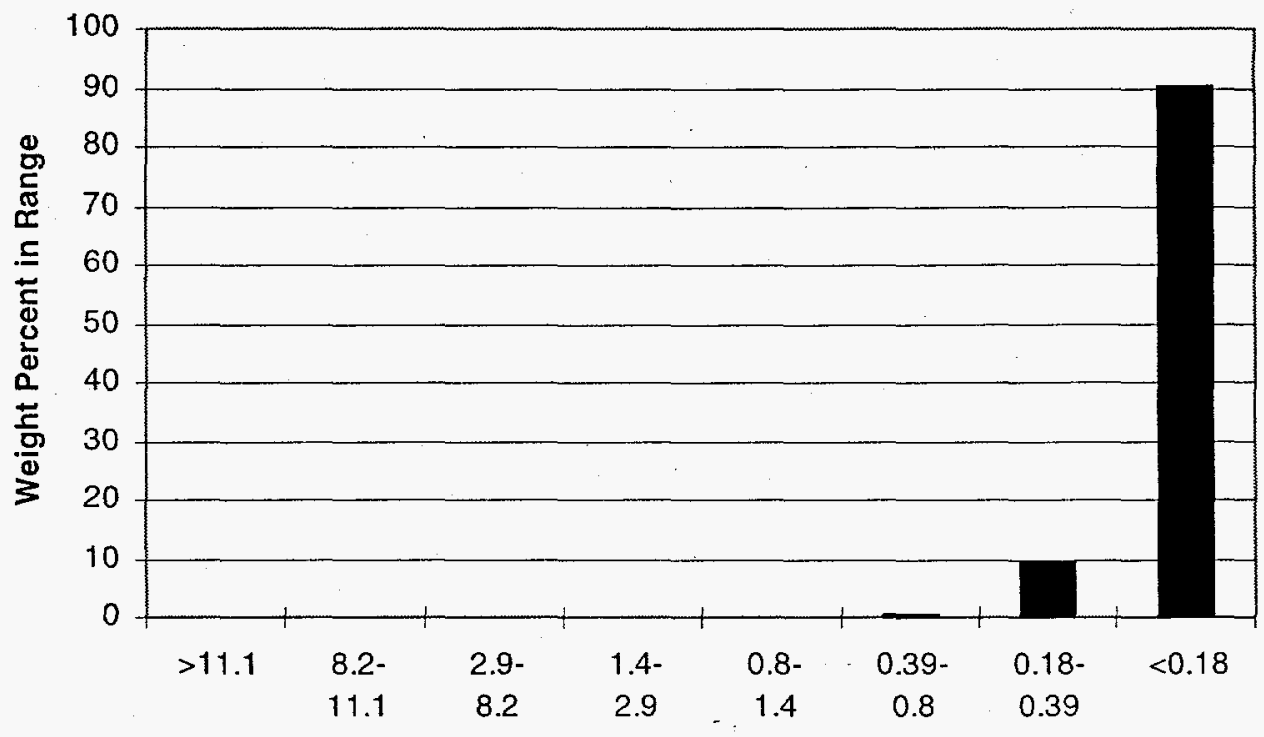

Aerodynamic Particle Diameter, $d_{50}(\mu \mathrm{m})$

Figure 13. Oxide Particle Size Distribution for Run 6

The elemental analysis of the $0.18-0.39 \mu \mathrm{m}$ and $<0.18 \mu \mathrm{m}$ filter paper stages showed that only $\mathrm{PbO}$ was present. No material was collected in the impingers. The total particulate concentration was $0.0447 \mathrm{mg} / \mathrm{dscf}(0.0392 \mathrm{mg} /$ wet $\mathrm{scf})$ and the $\mathrm{PbO}$ was 0.0167 $\mathrm{mg} /$ dscf $(0.0146 \mathrm{mg} /$ wet scf).

\section{Comparison of Runs}

The runs can be divided into the following comparison categories based on the experimental conditions:

\begin{tabular}{ll} 
Runs & Effect \\
\hline 1 vs. 5 & Steam to Film Cooler (Melter Location) \\
2 vs. 6 & Steam to Film Cooler (HEME Location) \\
1 vs. 2 \& $5 . v s .6$ & Melter vs. HEME \\
1 vs. 3 & $1450^{\circ} \mathrm{C}$ vs. $1150^{\circ} \mathrm{C}$ \\
1 vs. 4 & Feeding vs. Idling
\end{tabular}

These comparisons are made in Tables VIII-XII. The total particulate collected on the filter papers, the calculated amounts of oxides (or nitrates) on the filter papers, sample line, and impingers, and the calculated amount of $\mathrm{PbO}$ are given in these tables. The evolution rate rather than the concentrations are compared since the offgas flowrates were not necessarily the same between runs. The total concentrations are also given for reference.

Comparison of Runs 1 and 5 (see Table VIII) shows that both the total particulate and $\mathrm{PbO}$ collected at the melter location were decreased by use of steam to the film cooler. For both of these runs, $\mathrm{Pb}$ was the most prevalent particulate collected and was 
captured on the later stages of the impactor, indicating a particle size of less than about $0.3 \mu \mathrm{m}$. Note that the total particulate reported for Run 5 excludes the particulate collected on the first two stages of the impactor; these were excluded since it was determined that the particulate collected on these stages was mostly lanthanides that were apparently "cleaned" from the deposits on the film cooler and/or offgas line from Run 4, during which the melter was fed.

The most likely explanation for the decrease in $\mathrm{PbO}$ evolution during steam use is cooling of the surface of the glass. Visual observations have shown that when the air flow to the film cooler is increased, the surface of the glass becomes darker red, indicating it is being cooled more. The amount of cooling provided by steam is greater than that provided by air due to its higher heat capacity and absorption of infrared radiation, so use of steam should result in more cooling than an equivalent amount of air. The decreases in total particulate and $\mathrm{PbO}$ evolution were about $1.5 \mathrm{X}$ and $2 \mathrm{X}$, respectively.

Table VIII. Comparison of Runs 1 and 5: Melter Location No Steam vs. Steam

\begin{tabular}{|c|c|c|c|c|c|}
\hline Run and Conditions & $\begin{array}{c}\text { Sample } \\
\text { Line } \\
\text { (mg/min) }\end{array}$ & $\begin{array}{c}\text { Filters } \\
\text { (mg/min) }\end{array}$ & $\begin{array}{l}\text { Impingers } \\
(\mathrm{mg} / \mathrm{min})\end{array}$ & $\begin{array}{c}\text { Total } \\
\text { (mg/min) }\end{array}$ & $\begin{array}{c}\text { Concentration } \\
\text { (mg/wet scf) }\end{array}$ \\
\hline \multicolumn{6}{|l|}{ Total Particulate } \\
\hline 1 No Steam & & 9.00 & & 9.00 & 0.200 \\
\hline 5 Steam & & $5.74^{\mathrm{a}}$ & & 5.74 & 0.0764 \\
\hline \multicolumn{6}{|l|}{ Total Oxides } \\
\hline 1 No Steam & $\mathrm{NA}^{\mathrm{C}}$ & 5.72 & 0 & 5.72 & 0.127 \\
\hline 5 Steam $^{b}$ & 0.703 & 2.49 & 0.160 & 3.35 & 0.0446 \\
\hline \multicolumn{6}{|l|}{$\mathrm{PbO}$} \\
\hline 1 No Steam & $\mathrm{NAc}^{\mathrm{c}}$ & 5.65 & 0 & 5.65 & 0.126 \\
\hline 5 Steam & 0.385 & 2.41 & 0 & 2.85 & 0.0380 \\
\hline
\end{tabular}

a Stages 1 \& 2 not included since they contained material "cleaned" from the film cooler and offgas line.

b Boron not included in calculated oxides.

c Sample Line amounts are included with the Filters.

Comparison of Runs 2 and 6 (Table IX) for sampling from the HEME location with and without steam to the film cooler resulted in similar conclusions. The amount of total particulate, total oxides, and $\mathrm{PbO}$ are all much less when steam is used. The decrease resulting from steam use is about $4 \mathrm{X}$. 
Table IX. Comparison of Runs 2 and 6: HEME Location No Steam vs. Steam

\begin{tabular}{|c|c|c|c|c|c|}
\hline Run and Conditions & $\begin{array}{c}\text { Sample } \\
\text { Line } \\
\text { (mg/min) }\end{array}$ & $\begin{array}{c}\text { Filters } \\
\text { (mg/min) }\end{array}$ & $\begin{array}{l}\text { Impingers } \\
\text { (mg/min) }\end{array}$ & $\begin{array}{c}\text { Total } \\
\text { (mg/min) }\end{array}$ & $\begin{array}{c}\text { Concentration } \\
\text { (mg/wet scf) }\end{array}$ \\
\hline \multicolumn{6}{|l|}{ Total Particulate } \\
\hline 2 No Steam & & 8.03 & & 8.03 & 0.170 \\
\hline 6 Steam & & 2.30 & 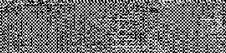 & 2.30 & 0.0392 \\
\hline \multicolumn{6}{|l|}{ Total Oxides } \\
\hline 2 No Steam & $\mathrm{NA}^{\mathrm{C}}$ & 4.89 & 0 & 4.89 & 0.104 \\
\hline 6 Steam & 0.180 & 0.860 & 0 & 1.039 & 0.0177 \\
\hline \multicolumn{6}{|l|}{$\mathrm{PbO}$} \\
\hline 2 No Steam & $N A^{c}$ & 4.89 & 0 & 4.89 & 0.104 \\
\hline 6 Steam & 0.0447 & 0.860 & 0 & 0.904 & 0.0154 \\
\hline
\end{tabular}

c Sample Line amounts are included with the Filters.

Comparison of Runs 1 and 2 (Table $X$ ) shows that there was about a 10\% decrease in the amount of particulate from the melter to the HEME, which indicates that the quencher/scrubber, as expected, is not an efficient device for removal of particulate smaller than about $10 \mu \mathrm{m}$. This decrease was seen for the total particulate, total oxides, and the $\mathrm{PbO}$. When steam was used, the absolute concentrations all were decreased, as noted before. In addition, the decrease from the melter to the HEME was higher than when steam was not used. A $60-70 \%$ decrease was found when steam was used, indicating that injection of steam apparently increases the efficiency of particulate removal from the system. The data tend to lead to the conclusion that the scrubber efficiency is improved by the use of steam. However, the apparent efficiency would also have increased if introduction of steam caused $\mathrm{PbO}$ to become less likely to precipitate out of the vapor phase as a particulate. (Whether or not $\mathrm{PbO}$ precipitation was affected by stream is a supposition; however, it would result in the same apparent increase in scrubbing efficiency as the assumption of increased scrubber efficiency. The data are not sufficient to determine which alternative is most likely to be correct.) The $\mathrm{PbO}$ would then not be removed by the filter papers and may also not be removed by the Method 29 impingers, such that the measured concentration would be less than the actual. Decreased likelihood of removal of the $\mathrm{PbO}$ would not reduce the actual concentration in the offgas system, but would have the desired effect of decreasing the possibility of plugging the HEME. 
Table X. Comparison of Runs 1 and 2: Melter vs. HEME and

Runs 5 and 6: Melter vs. HEME, Both With Steam

\begin{tabular}{|c|c|c|c|c|c|}
\hline $\begin{array}{l}\text { Run, Location, and } \\
\text { Conditions }\end{array}$ & $\begin{array}{c}\text { Sample } \\
\text { Line } \\
\text { (mg/min) }\end{array}$ & $\begin{array}{c}\text { Filters } \\
\text { (mg/min) }\end{array}$ & $\begin{array}{l}\text { Impingers } \\
\text { (mg/min) }\end{array}$ & $\begin{array}{c}\text { Total } \\
(\mathrm{mg} / \mathrm{min})\end{array}$ & $\begin{array}{l}\text { Concentration } \\
\text { (mg/wet scf) }\end{array}$ \\
\hline \multicolumn{6}{|l|}{ Total Particulate } \\
\hline $\begin{array}{ll}1 & \text { Melter No Steam } \\
2 & \text { HEME No Steam }\end{array}$ & & $\begin{array}{l}9.00 \\
8.03\end{array}$ & & $\begin{array}{l}9.00 \\
8.03\end{array}$ & $\begin{array}{l}0.200 \\
0.170\end{array}$ \\
\hline 5 Melter Steam & & $5.74^{\mathrm{a}}$ & & 5.74 & 0.0764 \\
\hline 6 HEME Steam & & 2.30 & & 2.30 & 0.0392 \\
\hline \multicolumn{6}{|l|}{ Total Oxides } \\
\hline 1 Melter No Steam & $\mathrm{NA}^{\mathrm{c}}$ & 5.72 & $\overline{0}$ & 5.72 & 0.127 \\
\hline 2 HEME No Steam & $\mathrm{NA}^{\mathrm{C}}$ & 4.89 & 0 & 4.89 & 0.104 \\
\hline 5 Melter Steam $b$ & 0.703 & 2.49 & 0.160 & 3.35 & 0.0446 \\
\hline 6 HEME Steam & 0.180 & 0.860 & 0 & 1.039 & 0.0177 \\
\hline \multicolumn{6}{|l|}{$\mathrm{PbO}$} \\
\hline 1 Melter No Steam & $\mathrm{NA}^{\mathrm{c}}$ & 5.65 & 0 & 5.65 & 0.126 \\
\hline 2 HEME No Steam & $\mathrm{NA}^{\mathrm{C}}$ & 4.89 & 0 & 4.89 & 0.104 \\
\hline 5 Melter Steam & 0.385 & 2.41 & 0 & 2.85 & 0.0380 \\
\hline 6 HEME Steam & 0.0447 & 0.860 & 0 & 0.904 & 0.0154 \\
\hline
\end{tabular}

a Stages 1 \& 2 not included since they contained material "cleaned" from the film cooler and offgas line.

b Boron not included in calculated oxides.

c Sample Line amounts are included with the Filters.

The total particulate emissions versus idling temperature are shown in Table XI. The reduction in emissions was approximately 43X. The reduction in $\mathrm{PbO}$ emissions was not calculated since the $\mathrm{Pb}$ detected at the lower temperature was zero.

Total particulate evolution during feeding was found to be about 10X the amount determined during idling, as shown in Table XII. As previously discussed, this particulate essentially all consists of entrained surrogate feed. As noted before, the evolution of $\mathrm{PbO}$ is decreased by the presence of the cold cap, which both cools the surface of the glass and reduces the exposed glass surface area.

Table XI. Comparison of Runs 1 and 3: Effect of Temperature

\begin{tabular}{||lccc||}
\hline $\begin{array}{l}\text { Run, Location, and } \\
\text { Conditions }\end{array}$ & $\begin{array}{c}\text { Filters } \\
(\mathbf{m g} / \mathbf{m i n})\end{array}$ & $\begin{array}{c}\text { Total } \\
(\mathbf{m g} / \mathrm{min})\end{array}$ & $\begin{array}{c}\text { Concentration } \\
\text { (mg/wet scf) }\end{array}$ \\
\hline Total Particulate & & & \\
\hline 1 Melter $1450^{\circ} \mathrm{C}$ & 9.00 & 9.00 & 0.200 \\
3 Melter $1150^{\circ} \mathrm{C}$ & 0.208 & 0.208 & 0.00495 \\
\hline
\end{tabular}

Table XIII summarizes the data for the six runs presented in Tables VIII-XII. 
Table XII. Comparison of Runs 1 and 4: Melter Location No Feeding vs. Feeding

\begin{tabular}{|c|c|c|c|c|c|}
\hline Run and Conditions & $\begin{array}{l}\text { Sample Line } \\
(\mathrm{mg} / \mathrm{min})\end{array}$ & $\begin{array}{c}\text { Filters } \\
(\mathrm{mg} / \mathrm{min})\end{array}$ & $\begin{array}{c}\text { Impingers } \\
\text { (mg/min) }\end{array}$ & $\begin{array}{c}\text { Total } \\
(\mathrm{mg} / \mathrm{min})\end{array}$ & $\begin{array}{c}\text { Concentration } \\
\text { (mg/wet scf) }\end{array}$ \\
\hline \multicolumn{6}{|l|}{ Total Particulate } \\
\hline $\begin{array}{l}1 \text { Not Feeding } \\
4 \text { Feeding }\end{array}$ & & $\begin{array}{r}9.00 \\
79.5 \\
\end{array}$ & & $\begin{array}{r}9.00 \\
79.5 \\
\end{array}$ & $\begin{array}{l}0.200 \\
1.90 \\
\end{array}$ \\
\hline \multicolumn{6}{|l|}{ Total Oxide/Nitrate } \\
\hline 1 Not Feeding & $\mathrm{NAc}^{\mathrm{c}}$ & 5.72 & 0 & 5.72 & 0.127 \\
\hline 4 Feeding & 61.4 & 35.6 & 0.032 & 97.0 & 2.32 \\
\hline \multicolumn{6}{|l|}{$\mathrm{PbO}$} \\
\hline 1 Not Feeding & $\overline{N A C^{c}}$ & 5.65 & 0 & 5.65 & 0.126 \\
\hline 4 Feeding & 1.30 & 2.21 & 0 & 3.51 & 0.084 \\
\hline
\end{tabular}

c Sample Line amounts are included with the Filters.

Table XIII. Total Particulate, Oxide/Nitrate and PbO Summary

\begin{tabular}{|c|c|c|c|c|c|}
\hline $\begin{array}{l}\text { Run, Location, and } \\
\text { Conditions }\end{array}$ & $\begin{array}{c}\text { Sample } \\
\text { Line } \\
\text { (mg/min) }\end{array}$ & $\begin{array}{c}\text { Filters } \\
(\mathrm{mg} / \mathrm{min})\end{array}$ & $\begin{array}{l}\text { Impingers } \\
\text { (mg/min) }\end{array}$ & $\begin{array}{c}\text { Total } \\
(\mathrm{mg} / \mathrm{min})\end{array}$ & $\begin{array}{c}\text { Concentration } \\
\text { (mg/wet scf) }\end{array}$ \\
\hline \multicolumn{6}{|l|}{ Total Particulate } \\
\hline 1 Melter No Steam & & 9.00 & & 9.00 & 0.200 \\
\hline 2 HEME No Steam & & 8.03 & & 8.03 & 0.170 \\
\hline 3 Melter Low Temp & & 0.208 & & 0.208 & 0.00495 \\
\hline 4 Melter Feeding & & 79.5 & & 79.5 & 1.90 \\
\hline 5 Melter Steam & & $5.74^{\mathrm{a}}$ & & 5.74 & 0.0764 \\
\hline 6 HEME Steam & Xe & 2.30 & & 2.30 & 0.0392 \\
\hline \multicolumn{6}{|l|}{ Total Oxide/Nitrate } \\
\hline 1 Melter No Steam & $\mathrm{NA}^{\mathrm{C}}$ & 5.72 & 0 & 5.72 & 0.127 \\
\hline 2 HEME No Steam & $\mathrm{NAC}^{\mathrm{C}}$ & 4.89 & 0 & 4.89 & 0.104 \\
\hline 3 Melter Low Temp & NA & 0 & 0 & 0 & 0 \\
\hline 4 Melter Feeding & 61.4 & 35.6 & 0.032 & 97.0 & 2.32 \\
\hline 5 Melter Steamb & 0.703 & 2.49 & 0.160 & 3.35 & 0.0446 \\
\hline 6 HEME Steam & 0.180 & 0.860 & 0 & 1.039 & 0.0177 \\
\hline \multicolumn{6}{|l|}{$\mathrm{PbO}$} \\
\hline 1 Melter No Steam & $\mathrm{NA}^{\mathrm{C}}$ & 5.65 & 0 & 5.65 & 0.126 \\
\hline 2 HEME No Steam & $\mathrm{NAC}^{\mathrm{C}}$ & 4.89 & 0 & 4.89 & 0.104 \\
\hline 3 Melter Low Temp & NA & 0 & 0 & 0 & 0 \\
\hline 4 Melter Feeding & 1.30 & 2.21 & 0 & 3.51 & 0.084 \\
\hline 5 Melter Steam & 0.385 & 2.41 & 0 & 2.85 & 0.0380 \\
\hline 6 HEME Steam & 0.0447 & 0.860 & 0 & 0.904 & 0.0154 \\
\hline
\end{tabular}

a Stages 1 \& 2 not included since they contained material "cleaned" from the film cooler and offgas line.

b Boron not included in calculated oxides.

c Sample Line amounts are included with the Filters. 
The distribution of the collected material on the sample line, filter papers, and impingers for Runs 4-6 is given in Table XIV.

Table XIV. Distribution of Particulate in the Sampling System (Wt \%)

\begin{tabular}{|c|c|c|c|c|c|c|c|c|}
\hline & $\begin{array}{c}\text { Sample } \\
\text { Line }\end{array}$ & $\begin{array}{l}\text { Run } 4 \\
\text { Filter } \\
\text { Papers }\end{array}$ & Impingers & $\begin{array}{c}\text { Sample } \\
\text { Line }\end{array}$ & $\begin{array}{l}\text { Run } 5 \\
\text { Filter } \\
\text { Papers }\end{array}$ & Impingers & $\begin{array}{c}\text { Run } 6 \\
\text { Sample } \\
\text { Line }\end{array}$ & $\begin{array}{c}\text { Filter } \\
\text { Papers }\end{array}$ \\
\hline $\mathrm{Pb}$ & 37.0 & 63.0 & 0.0 & 13.5 & 86.5 & 0.0 & 4.9 & 95.1 \\
\hline B & 4.4 & 47.9 & 47.7 & 3.3 & 68.1 & 28.7 & 100 & 0 \\
\hline Ba & 37.6 & 62.4 & 0.0 & 100.0 & 0.0 & 0.0 & & \\
\hline $\mathrm{Ce}$ & 67.2 & 32.8 & 0.0 & 19.6 & 80.4 & 0.0 & 100 & 0 \\
\hline $\mathrm{Cr}$ & 58.9 & 41.1 & 0.0 & 100.0 & 0.0 & 0.0 & 100 & 0 \\
\hline Er & 67.1 & 32.9 & 0.0 & 0.0 & 100.0 & 0.0 & & \\
\hline $\mathrm{Eu}$ & 65.0 & 35.0 & 0.0 & & & & & \\
\hline $\mathrm{Fe}$ & 51.3 & 48.6 & 0.1 & 75.9 & 0.0 & 24.1 & 100 & 0 \\
\hline $\mathrm{Gd}$ & 72.4 & 27.6 & 0.0 & & & & & \\
\hline $\mathrm{La}$ & 66.5 & 33.5 & 0.0 & 0.0 & 100.0 & 0.0 & & \\
\hline $\mathrm{Mn}$ & 47.7 & 52.0 & 0.3 & 72.7 & 23.2 & 4.1 & 100 & 0 \\
\hline $\mathrm{Nd}$ & 66.1 & 33.9 & 0.0 & 4.0 & 96.0 & 0.0 & & \\
\hline $\mathrm{Pr}$ & 63.4 & 36.6 & 0.0 & 3.1 & 96.9 & 0.0 & & \\
\hline $\mathrm{Sm}$ & 67.3 & 32.7 & 0.0 & 0.0 & 100.0 & 0.0 & & \\
\hline Total & 59.1 & 37.5 & 3.4 & 7.3 & 73.0 & 19.7 & 17.3 & 82.7 \\
\hline
\end{tabular}

\section{CONCLUSIONS}

Note: The particulate evolution rates given are based on the particulate measured at the sample point. Deposition of particulate in the offgas line prior to the sample point is not quantified and therefore not included. Due to high uncertainties in background data, the results of elemental analyses of $\mathrm{B}, \mathrm{Ca}, \mathrm{Al}, \mathrm{Fe}$, etc. were discarded, while those of $\mathrm{Pb}$ and lanthanides were retained.

- During idling of the melter at $1450^{\circ} \mathrm{C}$, about $63 \mathrm{wt} \%$ of the particulate emitted was $\mathrm{PbO}$. The emission rate of $\mathrm{PbO}$ was $5.65 \mathrm{mg} / \mathrm{min}(0.126 \mathrm{mg} /$ wet $\mathrm{scf})$.

- Idling at $1150^{\circ} \mathrm{C}$ reduced the total particulate emissions from $9.00 \mathrm{mg} / \mathrm{min}$ to 0.21 $\mathrm{mg} / \mathrm{min}$.

- The particle size of the PbO emissions during idling is less than about $0.3 \mu \mathrm{m}$.

- During feeding of coupled surrogate feed/frit, about $85 \mathrm{wt} \%$ of the particulate was $1 \mu \mathrm{m}$ or larger. The particulate rate was about $10 \mathrm{X}$ the rate during idling at $1450^{\circ} \mathrm{C}$.

- During feeding, most of the offgas particulate is surrogate feed entrained most likely as nitrates. The remainder is mostly volatilized $\mathrm{PbO}$. 
- The presence of the cold cap during feeding reduced the evolution of $\mathrm{PbO}$. This reduction is due to reduced glass surface temperature and coverage of the glass surface by the cold cap.

- The use of steam to the film cooler decreases the PbO emissions during idling by cooling the melt surface more than an equivalent amount of air. The reduction seen was about $1.5-2 X$.

- The use of steam to the film cooler removes offgas deposits on the film cooler and offgas line.

- The addition of steam to the film cooler increases the efficiency of particulate removal (apparently in the venturi scrubber) prior to the HEME from about $10 \%$ to $60-70 \%$.

\section{REFERENCES}

[1] Pilat Mark 3 and Mark 5 Source Test Cascade Impactors (Manual), Pollution Control Systems Corp., P.O. Box 15570, $803635^{\text {th }}$ Avenue NE, Seattle, WA 98115.

[2] Atmospheric Environment, Vol. 4, pp. 671-679, Pergamon Press, 1970. .

[3] Method 29 - Determination of Metals Emissions from Stationary Sources, U. S. Environmental Protection Agency, 40 CFR 60.759.

[4] J. M. Harden, Offgas Sampling of the Am/Cm Melter, Clemson Environmental Technologies Laboratory Report performed under SCUREF Task Order SC0055, August 1997. 
APPENDIX A: Oxide Particle Size Distributions for Run 4

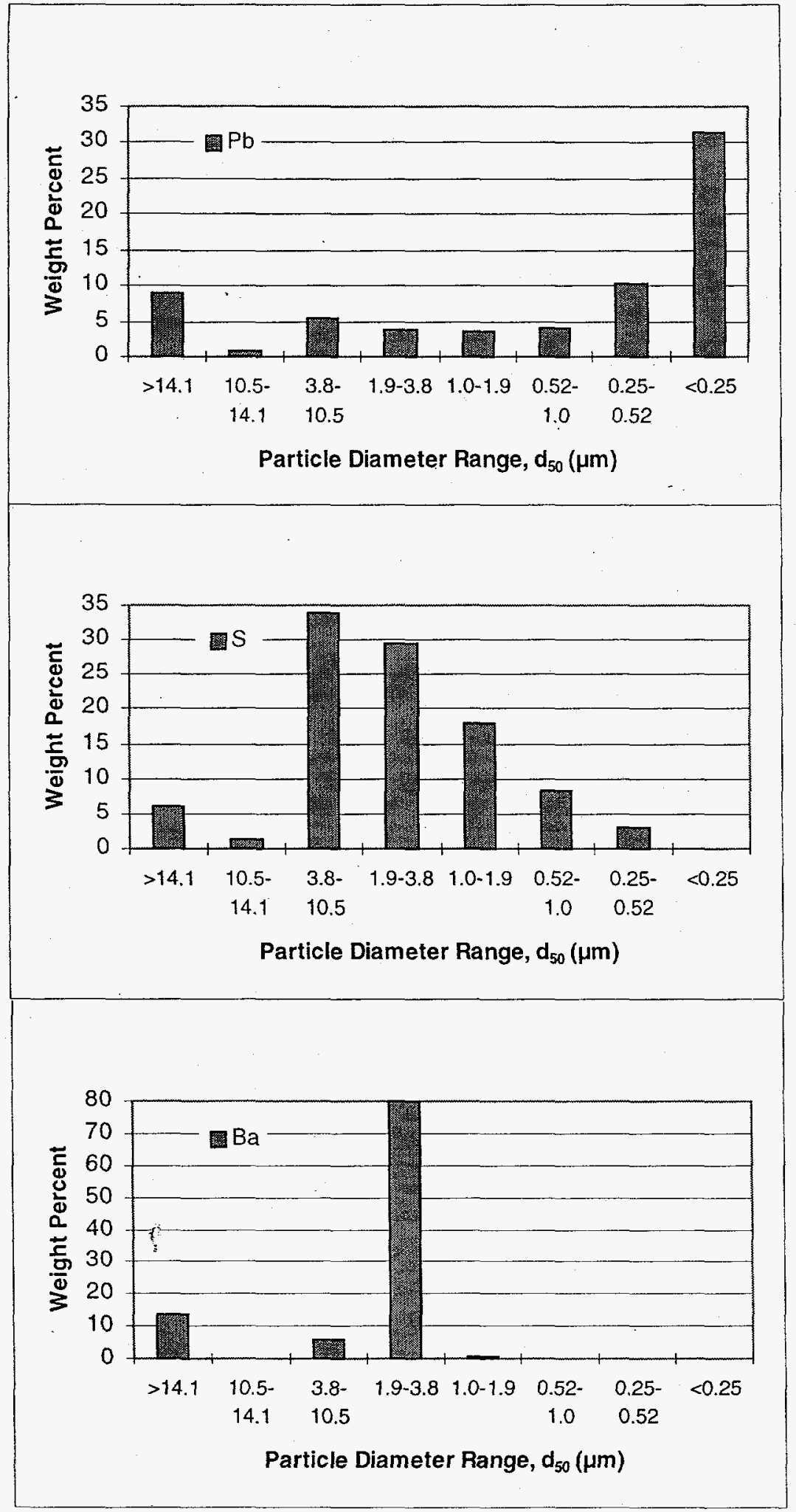




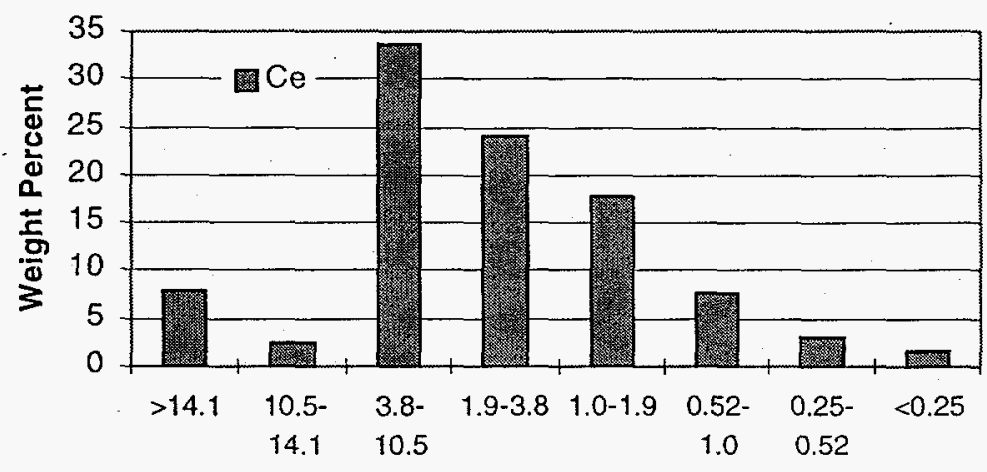

Particle Diameter Range, $d_{50}(\mu \mathrm{m})$

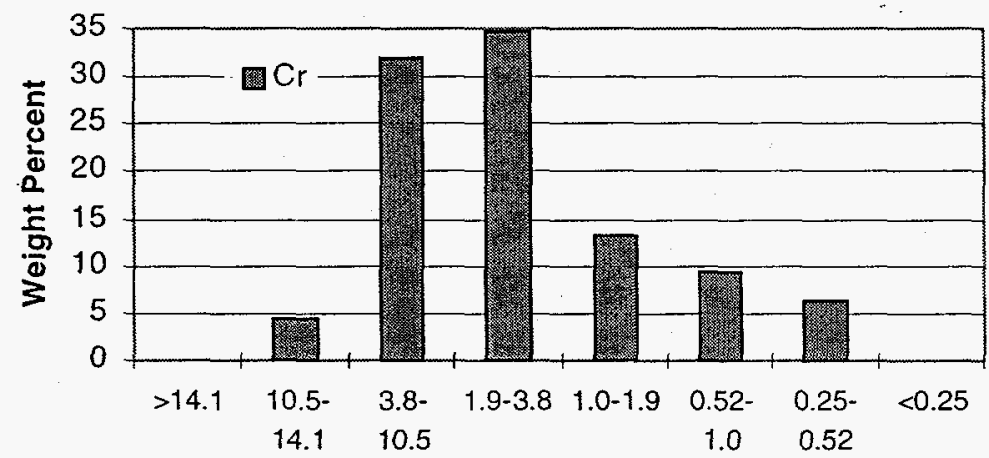

Particle Diameter Range, $d_{50}(\mu \mathrm{m})$

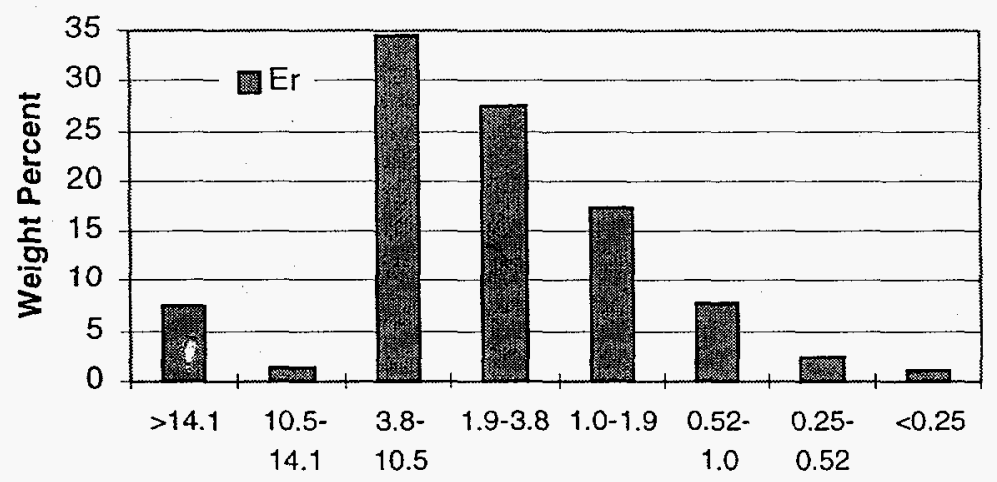

Particle Diameter Range, $d_{50}(\mu \mathrm{m})$ 


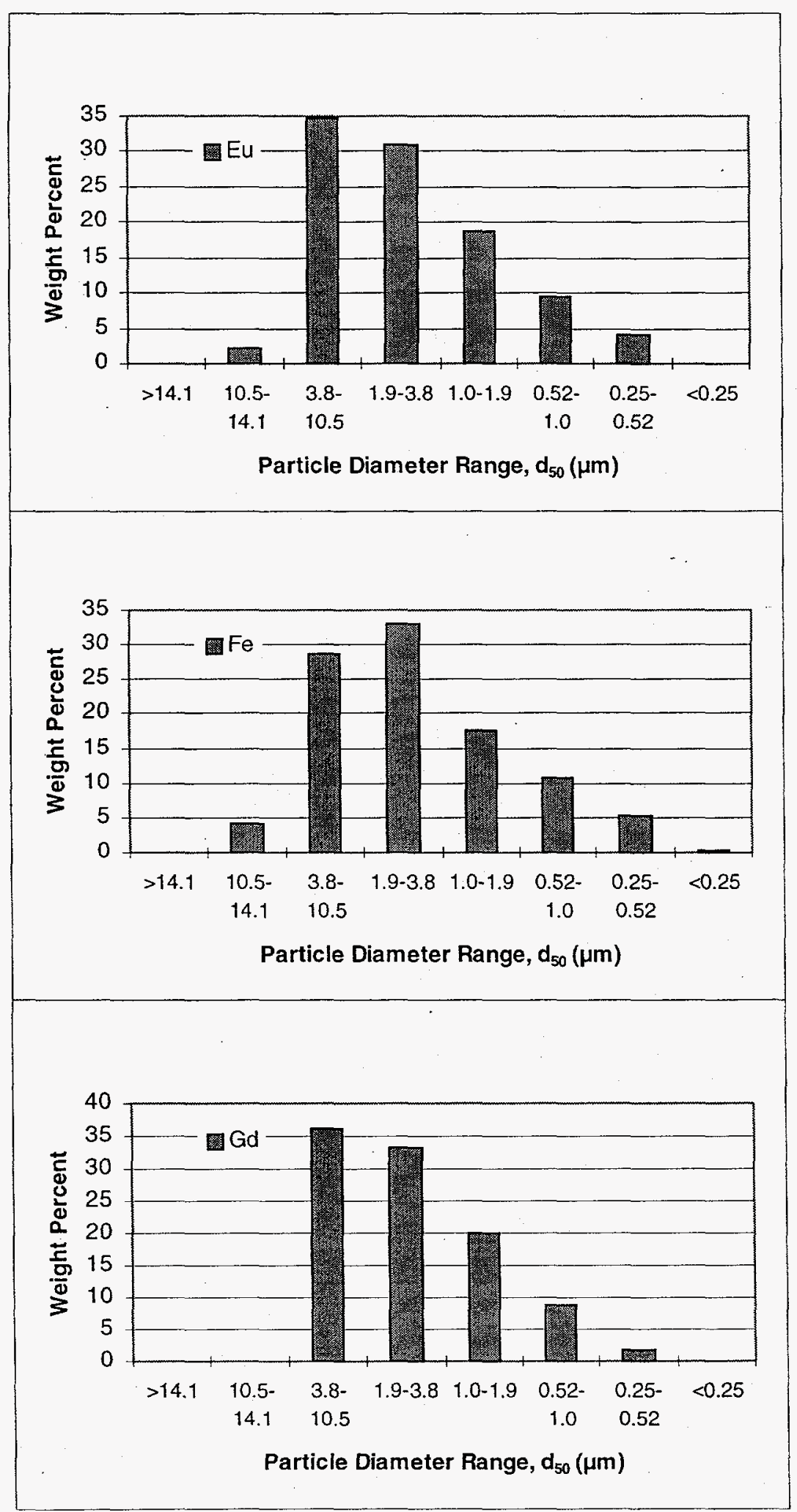




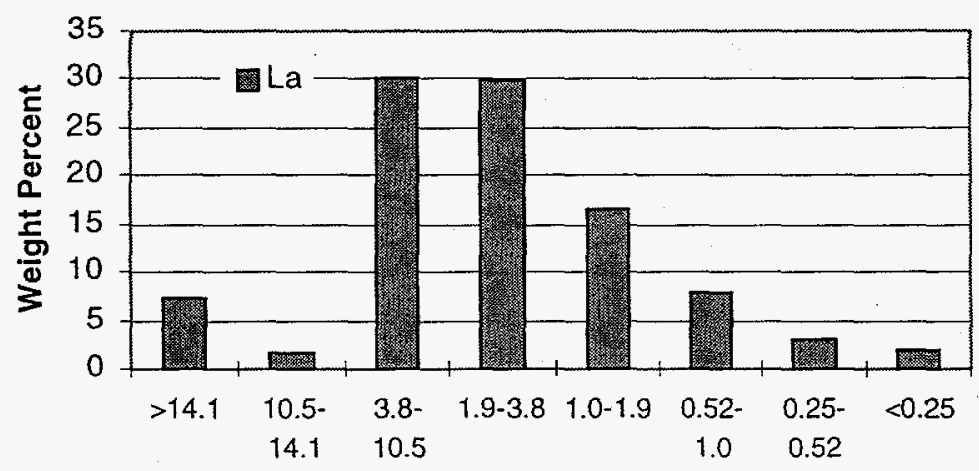

Particle Diameter Range, $d_{50}(\mu \mathrm{m})$

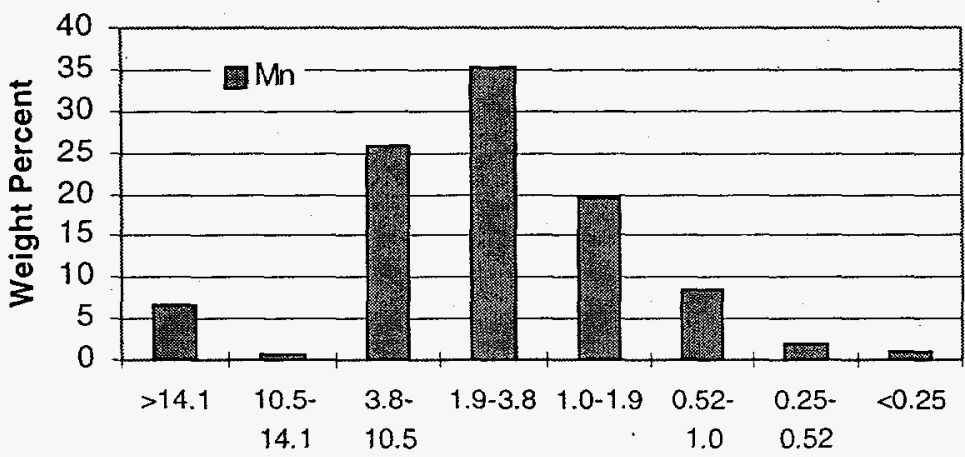

Particle Diameter Range, $d_{50}(\mu \mathrm{m})$

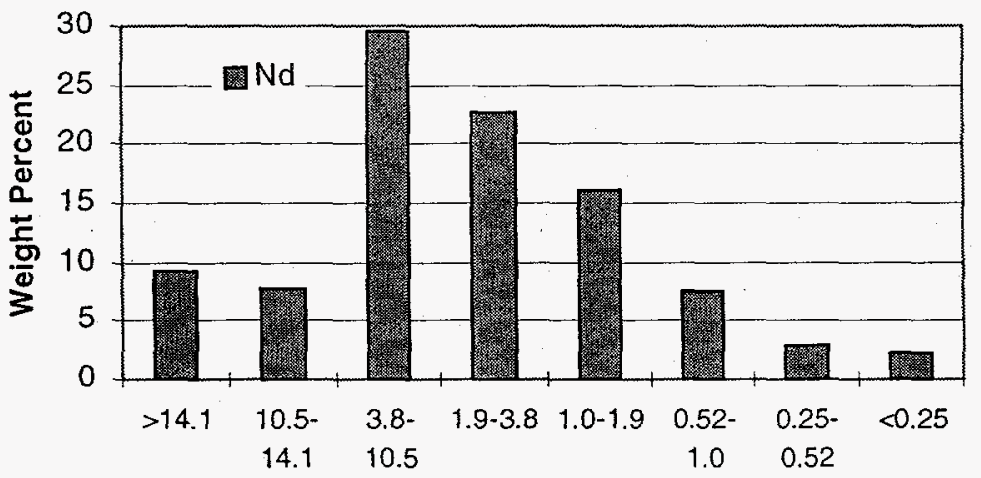

Particle Diameter Range, $d_{50}(\mu \mathrm{m})$ 


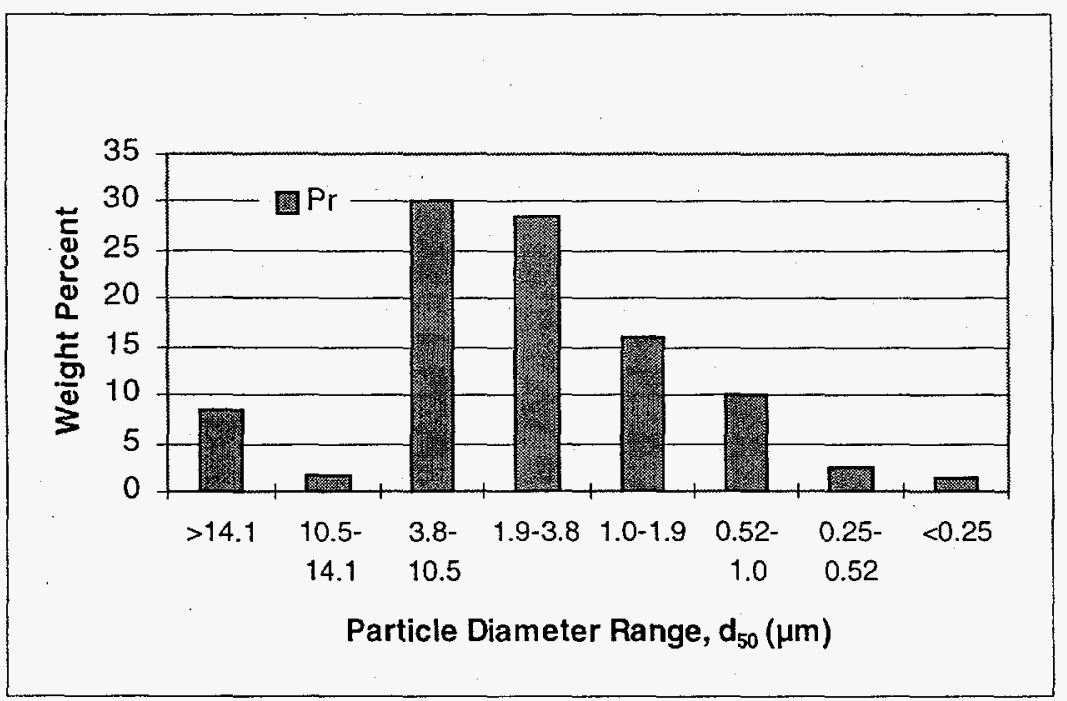




\section{Appendix B. Results of Am/Cm Vitrification Flowsheet Calculations}

\section{(8/97, A.S. Choi)}

\author{
Idling @ 1450 oc \\ (Clemson Run 18.2) \\ Idling @ 1150 oC \\ (Clemson Run 3) \\ Feed @ 1450 oc \\ (Clemson Run 4)
}

Idling w/ FC Stm

(Clemson Run 5\&6)
BASES:

liquid feed temp $(\mathrm{OC})=$ feed solids content, $S$ ( $g /$ /iter) $=$

oxide equiv, in feed ( $g$ /liter) =

HNO3 conc in feed, $M$ (molar) =

operating cycle @ 100\% attainment $(\mathrm{hr})=$

duration of feeding $(\mathrm{hr})=$

dur of pouring \& idling $(\mathrm{hr})=$

instantaneous glass prod. rate $(\mathrm{kg} / \mathrm{hr})=$

target waste loading in glass $(w t \%)=$

melt density @ $1450 \mathrm{oC}(\mathrm{g} / \mathrm{ml})=$

$w t \%$ glass entrainment $=$

$w t \% \mathrm{Cs}$ volatilized $=$

\section{CALCULATED RESULTS:}

melter feeds:

assumed liquid feed density $(\mathrm{g} / \mathrm{ml})=$

cal'd volatile density at fixed $M, S(\mathrm{~g} / \mathrm{ml})=$

cal'd liquid feed density $(\mathrm{g} / \mathrm{ml})=$

instantaneous liquid feed rate (liter/hr) $=$

$(\mathrm{gpm})=$

$(\mathrm{kg} / \mathrm{hr})=$

component liquid feed rates $(\mathrm{kg} / \mathrm{hr})$

salts $=$

$\mathrm{HNO} 3=$

$\mathrm{H} 2 \mathrm{O}=$

instantaneous frit 82000 feed rate $(\mathrm{kg} / \mathrm{hr})=$

avg. liquid feed rate over cycle (liter $/ \mathrm{hr}$ ) $=$ average frit feed rate over cycle $(\mathrm{kg} / \mathrm{hr})=$ avg. glass prod. rate over cycle $(\mathrm{kg} / \mathrm{hr})=$

$\mathrm{Pb} / \mathrm{B}$ volatilization \& glass entrainment: instant. rate of $\mathrm{PbO}$ volatilization $(\mathrm{g} / \mathrm{hr})=$ average rate of $\mathrm{PbO}$ volatilization $(\mathrm{g} / \mathrm{hr})=$ tofal PbO volatilized per cycle $(\% \mathrm{fed})=$ instant. rate of $\mathrm{B} 2 \mathrm{O} 3$ volatilization $(\mathrm{g} / \mathrm{hr})=$ average rate of $\mathrm{B} 2 \mathrm{O} 3$ volatilization $(\mathrm{g} / \mathrm{hr})=$ total $\mathrm{B} 2 \mathrm{O} 3$ volatilized per cycle $(\%$ fed $)=$ total $\mathrm{Na} 2 \mathrm{O}$ req'd to form $\mathrm{NaBO}$ (\% fed) = actual $\mathrm{Na} 2 \mathrm{O}$ used to form $\mathrm{NaBO} 2(\%$ fed $)=$ total $\mathrm{K} 2 \mathrm{O}$ req'd to form $\mathrm{KBO} 2$ (\% fed) = actual $\mathrm{K} 2 \mathrm{O}$ used to form $\mathrm{KBO} 2(\% \mathrm{fed})=$ instantaneous glass pour rate $(\mathrm{kg} / \mathrm{hr})=$ avg. glass pour rate over cycle $(\mathrm{kg} / \mathrm{hr})=$ air Inleakage \& purge $(\mathrm{kg} / \mathrm{hr})=$

$\begin{array}{rr}50 & 50 \\ 187.8420052 & 187.8420052 \\ 95.24526536 & 95.24526536 \\ 2.763352629 & 2.763352629 \\ 5 & 5 \\ 2 & 2 \\ 3 & 3 \\ 0 & 0 \\ 35 & 35 \\ 3.7 & 3.7 \\ 2 & 2 \\ 20 & 20\end{array}$

187.8420052

95.24526536

2.763352629

5

2

3

0

35

3.7

2

20

50

50

187.8420052

95.24526536

2.763352629

5

2

3

0

35

3.7

2

20

20

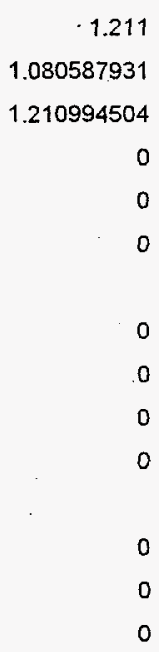

2.241780962
1.681335722
N/A
0.618034907
0.463526181
N/A
N/A
N/A
N/A
N/A
N/A
N/A
4.55

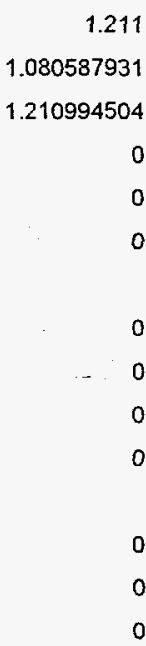

2.241780962
1.681335722
N/A
0.618034907
0.463526181
N/A
N/A
N/A
N/A
N/A
N/A
N/A
4.55

$$
\begin{array}{r}
2.241780962 \\
1.681335722 \\
3.748797596 \\
0.618034907 \\
0.463526181 \\
2.567808851 \\
229.6316219 \\
50 \\
229.6316219 \\
50 \\
0.698336229 \\
0.277754565 \\
4.55
\end{array}
$$

2.241780962 1.681335722

N/A

0.618034907

0.463526181

N/A

N/A

N/A

N/A

N/A

N/A

N/A

4:55

All mass rates shown represent instantaneous values during feeding or idling, except for $\mathrm{PbO}$ and borates whose rates are averaged over a cycle. 


\section{Appendix B. Results of $\mathrm{Am} / \mathrm{Cm}$ Vitrification Flowsheet Calculations}

(8/97, A.S. Choi)

Idling @ 1450 oC

(Clemson Run 1\&2)
Idling @ 1150 oC

(Clemson Run 3)
Feed @ 1450 oc

(Clemson Run 4)
Idling $w / F C$ Stm

(Clemson Run 5\&6)

melter off-gas:

off-gas to film cooler $(\mathrm{kg} / \mathrm{hr})$ :

$\mathrm{H} 2 \mathrm{O}=$

$\mathrm{HNO3}=$

NOX $=$

$\mathrm{SO} 2=$

$\mathrm{FeCl} 3=$

$\mathrm{NaF}=$

$\mathrm{PbO}=$

$(\mathrm{Na}, \mathrm{K}) \mathrm{BO} 2=$

$\mathrm{O} 2=$

$\mathrm{N} 2=$

glass $=$

total off-gas $(\mathrm{kg} / \mathrm{hr})=$

$(\mathrm{b} / \mathrm{hr})=$

OG w/o particulate $(\mathrm{lb} / \mathrm{hr})=$

assumed temp $(\mathrm{OC})=$

pressure ("wc vac) =

MW (lb/lbmole) $=$

MW dry (lb/bmole) $=$

$\mathrm{Cp}(\mathrm{Btu} / \mathrm{b} / \mathrm{F})=$

volumetric flow $(\mathrm{acfm})=$

$$
(\mathrm{scfm})=
$$

solids loading (grain/scf) $=$

residence time $(\mathrm{sec})=$

heat loss due to $O G$ flow $(B t u / h r)=$
1.029448544

2.11694394

film cooler:

FC air flow@ 25 psig (lb/hr) =

$$
\text { assumed temp }(\mathrm{OC})=
$$$$
\mathrm{Cp}(\mathrm{Btu} / \mathrm{b} / \mathrm{F})=
$$

FC steam flow @ 65 psig (b/hr) =

$$
\text { assumed temp }(\mathrm{oC})=
$$$$
\mathrm{Cp}(\mathrm{Btu} / \mathrm{b} / \mathrm{F})=
$$

check for possible condensation in manifold $(A)$ :

assumed vapor outlet temp $(\varphi \mathrm{C})=$

temperature approach $(\mathrm{OC})=$

H2O PS eqn slope (psia/oC) $=$

H2O PS eqn intercept (psia) $=$

estimated condensation $(\mathrm{l} / \mathrm{h} / \mathrm{hr})=$

$$
\begin{aligned}
& \text { parameter } L= \\
& \text { parameter } U= \\
& \text { parameter } A= \\
& \text { parameter } B= \\
& \text { parameter } C=
\end{aligned}
$$

$-4993.634107$
0.13195

0

0

0

0.002241781

0.000718608

3.388601456

4.552960389

10.03755937

10.03103283

500

3

28.34640756

28.84

0.257578397

6.066491402

0.359683503

0.494519781

4244.4

0.13195

0

0

0

0

0

0.002241781

0.000718608

1.029448544

3.388601456

4.552960389

10.03755937

10.03103283

300

3

28.34640756

28.84

0.257578397

4.497199181

2.11694394

0.359683503

0.667081861

2566.08

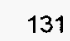

110

0.24

0

156

0.48

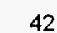

0

0.0807

$-2.157$

$-3.534696649$

609

82.75134483

6.009785434

200281.9878

0.48

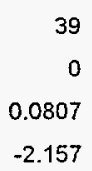

$-2.004171657$

609

83.38303448

6.055661659

$-4955.056171$

185910.0481

$$
\begin{array}{r}
2.360569272 \\
0.456955039 \\
0.167392472 \\
0.003804961 \\
0.000911154 \\
2.98547 \mathrm{E}-05 \\
0.001681336 \\
0.0005641 \\
1.099784936 \\
3.388601456 \\
0.014276172 \\
7.494570752 \\
16.52270006 \\
16.48420158 \\
300 \\
3 \\
\hline 25.06498056 \\
\hline 29.11175227 \\
0.337238229 \\
\hline 8.35785905 \\
3.934252932 \\
1.141637096 \\
0.358943598 \\
9164.494946
\end{array}
$$

0.13195

0
0
0
0
0

0.002241781

0.000718608

1.029448544

3.388601456

4.552960389

10.03755937

10.03103283

350

3

28.34640756

28.84

0.257578397

4.889522237

2.11694394

0.359683503

0.613556878

1038.96
132

95

0.24

0

156

0.48

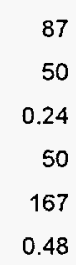

0.48

$$
\begin{array}{r}
41 \\
0 \\
0.0807 \\
-2.157 \\
-3.03626688 \\
609 \\
83.38303448 \\
6.055661659 \\
-4993.404811 \\
193860.453
\end{array}
$$

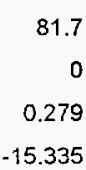

$-2.758342156$

609

104.957

27.74868156

$-21820.14009$

1597453.655 


\section{Appendix B. Results of Am/Cm Vitrification Flowsheet Calculations}

$$
\text { (8/97, A.S. Choi) }
$$

\begin{tabular}{|c|c|c|c|c|c|}
\hline & & $\begin{array}{l}\text { Idling } 1450 \text { oC } \\
\text { (Clemson Run 1\&2) }\end{array}$ & $\begin{array}{l}\text { Idling@1150 oc } \\
\text { (Clemson Run 3) }\end{array}$ & $\begin{array}{l}\text { Feed @ } 1450 \text { oc } \\
\text { (Clemson Run 4) }\end{array}$ & $\begin{array}{l}\text { Idling w/ FC Stm } \\
\text { (Clemson Run 5\&6) }\end{array}$ \\
\hline \multicolumn{2}{|l|}{ cal'd vapor outlet temp $(\mathrm{oC})=$} & 42.25641793 & 39.41817916 & 40.84668466 & 81.69812602 \\
\hline \multicolumn{2}{|l|}{ cal'd liquid outlet temp $(\mathrm{oC})=$} & 42.25641793 & 39.41817916 & 40.84668466 & 81.69812602 \\
\hline \multicolumn{2}{|l|}{ moisture condensed $(\mathrm{lb} / \mathrm{hr})=$} & N/A & N/A & N/A & -2.750405252 \\
\hline \multicolumn{2}{|l|}{$\%$ moisture condensed = } & N/A & N/A & N/A & -5.500810504 \\
\hline \multicolumn{2}{|l|}{ total film cooling medium $(\mathrm{lb} / \mathrm{hr})=$} & 131 & 132 & 132 & 137 \\
\hline \multicolumn{2}{|l|}{ temp $(o C)=$} & 110 & 80 & 95 & 112.5668449 \\
\hline \multicolumn{2}{|c|}{$\mathrm{Cp}(\mathrm{Btu} / \mathrm{b} / \mathrm{F})=$} & 0.24 & 0.24 & 0.24 & 0.327591241 \\
\hline \multicolumn{2}{|c|}{$\mathrm{MW}(\mathrm{l} / \mathrm{b} / \mathrm{bmole})=$} & 28.84 & 28.84 & 28.84 & 23.65601733 \\
\hline \multicolumn{6}{|c|}{ next calc valid when $F C$ medium $T<100 \circ C$} \\
\hline \multicolumn{6}{|c|}{ check for possible condensation @ $\mathrm{FC}$ exit (A): } \\
\hline \multicolumn{2}{|l|}{ assumed vapor ouflet temp $(\mathrm{oC})=$} & 45 & 40.9 & 51.5 & 80.6 \\
\hline \multicolumn{2}{|l|}{ temperature approach $(\mathrm{OC})=$} & 0 & 0 & 0 & 0 \\
\hline \multicolumn{2}{|l|}{ H2O PS eqn slope $(p s i a / o C)=$} & 0.0807 & 0.0807 & 0.0807 & 0.279 \\
\hline \multicolumn{2}{|l|}{ H2O PS eqn intercept (psia) $=$} & -2.157 & -2.157 & -2.157 & -15.335 \\
\hline \multicolumn{2}{|l|}{ estimated condensation $(\mathrm{lb} / \mathrm{hr})=$} & -5.541626207 & -3.218984785 & -4.763396092 & -3.92280986 \\
\hline \multicolumn{2}{|l|}{ parameter $L=$} & 609 & 609 & 609 & 609 \\
\hline \multicolumn{2}{|l|}{ parameter $U=$} & 89.65436647 & 90.29007313 & 103.1885732 & 111.6832735 \\
\hline \multicolumn{2}{|l|}{ parameter $\mathrm{A}=$} & 6.507974667 & 6.554019461 & 7.335400892 & 29.44540321 \\
\hline \multicolumn{2}{|l|}{ parameter $B=$} & -5490.323002 & -5410.244826 & -6263.654917 & -23348.43229 \\
\hline \multicolumn{2}{|l|}{ parameter $\mathrm{C}=$} & 233545.8638 & 210533.546 & 302909.4323 & 1689899.317 \\
\hline \multicolumn{2}{|l|}{ cal'd vapor outlet temp $(\mathrm{OC})=$} & 44.93067916 & 40.94476188 & 51.4612448 & 80.56256579 \\
\hline \multicolumn{2}{|l|}{ cal'd liquid outlet temp $(\mathrm{oC})=$} & 44.93067916 & 40.94476188 & 51.4612448 & 80.56256579 \\
\hline \multicolumn{2}{|l|}{ moisture condensed $(\mathrm{lb} / \mathrm{hr})=$} & -5.500988662 & -3.244142761 & -4.736561499 & -3.760342646 \\
\hline \multicolumn{2}{|l|}{$\%$ moisture condensed $=$} & -1891.024258 & -1115.209108 & -76.25375828 & -1292.658393 \\
\hline off-gas at film cooler exit $(\mathrm{lb} / \mathrm{hr})=$ & & 141.0375594 & 142.0375594 & 148.5227001 & 147.0375594 \\
\hline & $\mathrm{H} 2 \mathrm{O}=$ & 4.089899952 & 4.118899952 & 9.032164366 & 52.81389995 \\
\hline & $\mathrm{H} 2 \mathrm{Ol}=$ & 0 & 0 & 0 & 0 \\
\hline & HNO3 = & 0 & 0 & 1.007413405 & 0 \\
\hline & $\mathrm{HNO} 3 \mathrm{I}=$ & 0 & 0 & 0 & 0 \\
\hline & NOx $=$ & 0 & 0 & 0.369037226 & 0 \\
\hline & $\mathrm{SO} 2=$ & 0 & 0 & 0.008388503 & 0 \\
\hline & $\mathrm{FeCl} 3=$ & 0 & 0 & 0.002008752 & 0 \\
\hline & $\mathrm{NaF}=$ & 0 & 0 & $6.58182 E-05$ & 0 \\
\hline & $\mathrm{PbO}=$ & 0.004942281 & 0.004942281 & 0.003706711 & 0.004942281 \\
\hline$f$ & $(\mathrm{Na}, \mathrm{K}) \mathrm{BO} 2=$ & 0.00158426 & 0.00158426 & 0.001243627 & 0.00158426 \\
\hline 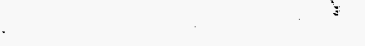 & $02=$ & $31.90861349^{\circ}$ & 32.13486591 & 32.28993111 & 21.95350669 \\
\hline & $\mathrm{N} 2=$ & 105.0325194 & 105.777267 & 105.777267 & 72.26362619 \\
\hline & glass $=$ & 0 & 0 & 0.03147357 & 0 \\
\hline temp @FC exit & $(\mathrm{OC})=$ & 139.6167341 & 96.58985267 & 125.6026734 & 125.4919521 \\
\hline pressure ("wc v & ac) $=$ & 3.5 & 3.5 & 3.5 & 3.5 \\
\hline $\mathrm{MW}$ (lb/bmole & & 28.34640756 & 28.34640756 & 27.94032485 & 23.72333052 \\
\hline MW dry (lb/lbm & ole) $=$ & 28.84 & 28.84 & 28.8599897 & 28.84 \\
\hline $\mathrm{Cp}(\mathrm{Btu} / \mathrm{b} / \mathrm{F})$ & $=$ & 0.25767157 & 0.25767162 & 0.266514477 & 0.333272031 \\
\hline total moisture & $(\mathrm{b} / \mathrm{hr})=$ & 4.0898999952 & 4.118899952 & 10.03957777 & 52.81389995 \\
\hline
\end{tabular}




\section{Appendix B. Results of Am/Cm Vitrification Flowsheet Calculations}

\section{(8/97, A.S. Choi)}

\author{
Idling @ 1450 oC \\ (Clemson Run 182)

$\begin{array}{rr}45.59190947 . & 41.12897771 \\ 29.76311566 & 29.97415514 \\ 0.025583001 & 0.025402878 \\ 2.067 & 2.067 \\ 32.60832986 & 29.41634355\end{array}$ \\ Idling@ 1150 oC \\ (Clemson Run 3) \\ 41.12897771 \\ 29.41634355
}

$(\mathrm{scfm})=$

solids loading $($ grain $/ \mathrm{scf})=$

effective film cooler I.D. (in) $=$

off-gas velocity @ FC exit (ft/sec) =

check max moisture content:

H2O PS eqn slope $(p s i a / o C)=$

H2O PS eqn intercept (psia) $=$

max moisture limit $(\mathrm{lb} / \mathrm{hr})=$

melter pressure control air:

25 psig control air flow $(\mathrm{lb} / \mathrm{hr})=$

$$
\begin{aligned}
& \text { temp }(\mathrm{oC})= \\
& C_{p}(\mathrm{Btu} / \mathrm{b} / \mathrm{F})=
\end{aligned}
$$

check for possible condenstion ( $A$ or $C$ )

assumed vapor outlet temp $(O C)=$

temperature approach $(\mathrm{OC})=$

H2O PS eqn slope (psia/oC) $=$

$\mathrm{H} 2 \mathrm{O}$ PS eqn intercept $(p s i a)=$

estimated condensation $(\mathrm{lb} / \mathrm{hr})=$

parameter $L=$
parameter $U=$
parameter $A=$
parameter $B=$
parameter $C=$

cal'd vapor outlet temp $(\mathrm{OC})=$

cal'd liquid outlet temp $(O C)=$

moisture condensed $(\mathrm{b} / \mathrm{hr})=$

$\%$ moisture condensed $=$

off-gas flow to steam jet $(\mathrm{lb} / \mathrm{hr})=$

$\mathrm{H} 2 \mathrm{O}=$

$\mathrm{H} 2 \mathrm{OI}=$

$\mathrm{HNO} 3=$

$\mathrm{HNO} 31=$

NOX $=$

$\mathrm{SO} 2=$

$\mathrm{FeCl} 3=$

$\mathrm{NaF}=$

$\mathrm{PbO}=$

$(\mathrm{Na}, \mathrm{K}) \mathrm{BO} 2=$

$\mathrm{O} 2=$

$\mathrm{N} 2=$

glass $=$

temp w/ ctrl air (oC) =

pressure ("wc vac) = volumetric flow $(\mathrm{acfm})=$
0.279

$-15.335$

No Limit

0.279

$-15.335$

338.0995926

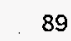

35

0.24

41.5

0

0.0807

$-2.157$

$-5.795397988$

609

146.2363369

10.79316215

$-8834.518735$

348344.5952

41.53786604

41.53786604

$-5.83021747$

$-142.5515914$

230.0375594

6.670899952

213.0375594

6.177899952

607.2267234

135.4293238

10.01182732

$-8063.966266$

300893.1471

39.22338898

39.22338898

$-3.455156471$

.83 .8854187

0.177899952

0

0

$\overbrace{0}^{0}$

0

0

0.004942281

0.00158426

48.19878824

158.6543446

171.3150534

100.8895173

4.5

77.02404886

4.5
$-3.435783107$

Feed @ 1450 oC
(Clemson Run 4)
47.04558114
31.79146413
0.141279718
2.067
33.64802759

Idling $w / F C$ Stm

(Clemson Run 58.6)

54.85077678

37.07618846

0.020536896

2.067

39.23047406

0.279

$-15.335$

$-15.335$

No Limit

No Limit

$\begin{array}{rr}53 & 79 \\ 35 & 35 \\ 0.24 & 0.24\end{array}$

0.24

73.4

0.279

$-15.335$

$-4.995183219$

609

138.037497

10.01349392

$-8336.707475$

374253.7153

47.61552341

47.61552341

$-5.009125247$

$-49.893784$

201.5227001

10.56916437

1.007413405

0

0.369037226

0.008388503

0.002008752

6.58182E-05

0.003706711

0.001243627

44.28130976

145.2488883

0.03147357

103.5684479

$-3.374582915$

609

161.9081774

42.45145659

$-33148.74632$

2203452.887

73.36451036

73.36451036

$-3.200551526$

$-6.060055267$

226.0375594

55.10489995

0

0

0

0

0

0

0.004942281

0.00158426

39.82744844

100.2471184

4.5

4.5
0

131.0986844 


\section{Appendix B. Results of Am/Cm Vitrification Flowsheet Calculations}

(8/97, A.S. Choi)

MW (lb/lbmole) $=$
$\mathrm{MW}$ dry (lb/bmole) =
$\mathrm{Cp}(\mathrm{Btu} / \mathrm{b} / \mathrm{F})=$
total moisture $(\mathrm{lb} / \mathrm{hr})=$
volumetric flow (acfm) $=$
\[ (\mathrm{scfm})= \]
solids loading (grain/scf) $=$

off-gas line I.D. (in) $=$

off-gas velocity $(\mathrm{ft} / \mathrm{sec})=$

check max moisture content:

H2O PS eqn slope $(p s i a / o C)=$

H2O PS eqn intercept (psia) =

max moisture limit $(\mathrm{lb} / \mathrm{hr})=$

steam jet:

steam supply pressure $(p s i g)=$

$$
\begin{aligned}
& \text { pressure ratio }= \\
& \text { max mass ratio }= \\
& \text { excess steam }(\% \mathrm{~min})=
\end{aligned}
$$

actual steam flow $(\mathrm{l} b / \mathrm{hr})=$

$$
\begin{aligned}
& \text { temp }(\mathrm{oC})= \\
& \mathrm{Cp}(\mathrm{Btu} / \mathrm{b} / \mathrm{F})=
\end{aligned}
$$

check for possible condensation $(E)$, Tro 100 :

assumed vapor outlet temp $(O C)=$

temperature approach $(\mathrm{OC})=$

$\mathrm{H} 2 \mathrm{O}$ PS eqn slope $(\mathrm{psia} / \mathrm{oC})=$

$\mathrm{H} 2 \mathrm{O}$ PS eqn intercept (psia) =

estimated condensation $(\mathrm{lb} / \mathrm{hr})=$

$$
\begin{aligned}
& \text { parameter } L= \\
& \text { parameter } U= \\
& \text { parameter } A= \\
& \text { parameter } B= \\
& \text { parameter } C=
\end{aligned}
$$

cal'd vapor outlet temp $(\mathrm{OC})=$

cal'd liquid outlet temp $(O C)=$

moisture condensed $(\mathrm{b} / \mathrm{hr})=$

$\%$ moisture condensed $=$

check for possible evaporation (F), Tvo $<100$ :

assumed vapor outlet temp (oC) $=$

temperature approach $(\mathrm{oC})=$

$\mathrm{H} 2 \mathrm{O}$ PS eqn slope $(\mathrm{psia} / \mathrm{oC})=$

H2O PS eqn intercept (psia) $=$

estimated evaporation $(\mathrm{l} b / \mathrm{hr})=$

parameter $L=$

parameter $\mathrm{U}=$

\author{
Idling@ 1450 oc \\ (Clemson Run 1\&2) \\ 28.34640756 \\ 28.84 \\ 0.258126824 \\ 6.670899952 \\ 67.55458129 \\ 48.54562927 \\ 0.015684827 \\ 2.067 \\ 48.31651264
}

0.279

$-15.335$

No Limit

.

25

347.5103878

8.974932376

25.6311189

25.63111896
131

0.48

61.4

0

0.163

$-6.89$

$-5.568672651$

609

171.8674559

26.25161923

$-20702.26451$

1172009.015

61.39184888

61.39184888

$-5.548160178$

$-21.64618793$

Idling @ $1150 \mathrm{oC}$
(Clemson Run 3)
28.34640756
28.84
0.258126473
6.177899952
58.5703366
44.95795813
0.016936486
2.067
41.89078453

Feed@1450 oc

(Clemson Run 4)

28.04601207

28.85456996

0.264629863

11.57657777

60.23316533

42.9765565

0.104510213

2.067

43.08007597

0.279

$-15.335$

94.89683072

$$
\begin{array}{r}
347.5103878 \\
8.974932376 \\
0 \\
23.73695427 \\
131 \\
0.48
\end{array}
$$

60.4

0

0.163

$-6.89$

$-2.858938645$

609

159.166278

24.31158635

$-18958.426$

1057180.315

60.44893393

60.44893393

$-2.969902655$

$-12.5117259$

0.279

$-15.335$

No Limit

25

347.5103878

8.974932376

22.45395192

131

0.48

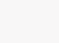

64
0
0.163
-6.89

$-4.745683922$

609

155.1952497

23.60240367

$-18728.71472$

1103066.273

64.07029035

64.07029035

$-4.911426249$

$-21.87332665$

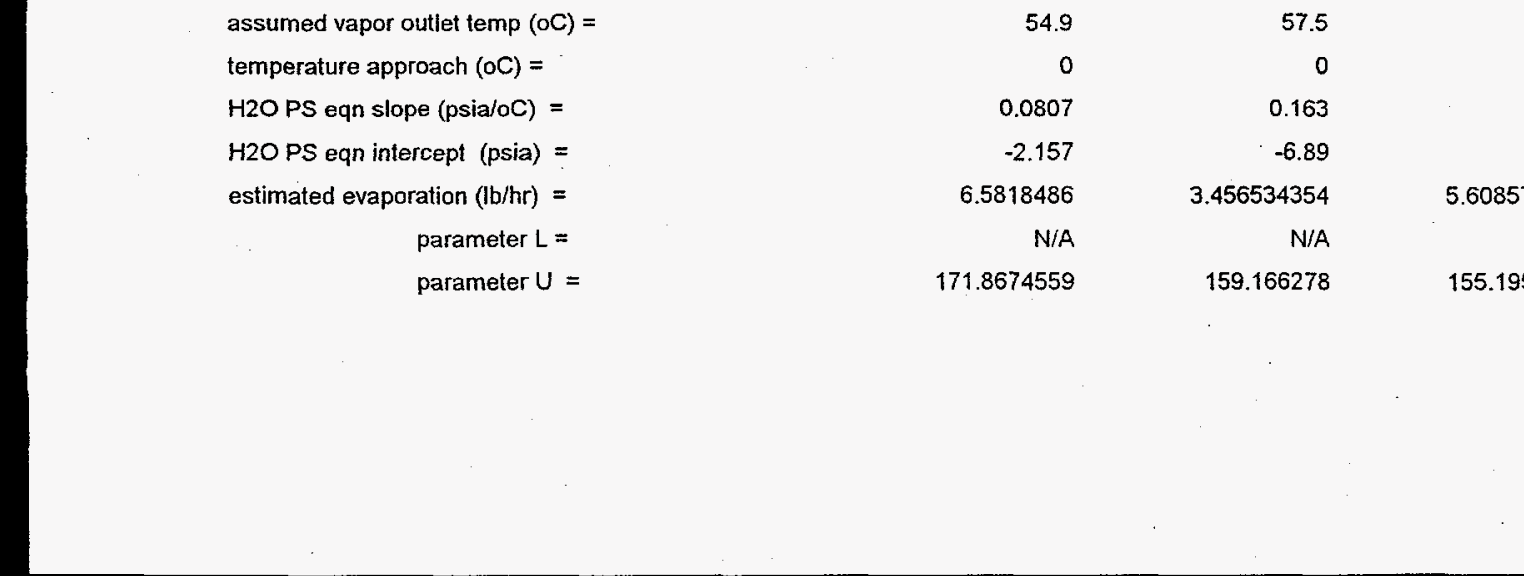

\author{
Idling $w /$ FC Stm \\ (Clemson Run 5\&6) \\ 25.15735688 \\ 28.84 \\ 0.307204604 \\ 55.10489995 \\ 74.6660088 \\ $\$ 3.74830728$ \\ 0.014166582 \\ 2.067 \\ 53.40276097
}

0.279

$-15.335$

No Limit

25

347.5103878

8.974932376

25.18543315

131

0.48

.

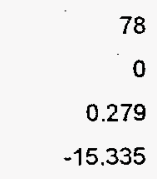

$-3.596460997$

609

187.0936106

49.89007257

$-38716.51334$

2717512.081

78.03734802

78.03734802

$-3.839599662$

$-15.24531914$ 


\section{Appendix B. Results of $\mathrm{Am} / \mathrm{Cm}$ Vitrification Flowsheet Calculations}

(8/97, A.S. Choi)

$\begin{array}{rrr}\begin{array}{c}\text { Idling @ 1450 oC } \\ \text { (Clemson Run 182) }\end{array} & \begin{array}{r}\text { Idling @ 1150 oC } \\ \text { (Clemson Run 3) }\end{array} & \begin{array}{r}\text { Feed @ 1450 oC } \\ \text { (Clemson Run 4) }\end{array} \\ 5.784721392 & 10.82065263 & 10.44805431 \\ 5910.041256 & 12089.92465 & 11581.9499 \\ -341884.5172 & -731118.7793 & -723441.0135 \\ 54.89817334 & 57.5129236 & 59.29149096 \\ 54.89817334 & 57.5129236 & 59.29149096 \\ 6.583823643 & 3.429482306 & 5.626105279 \\ 0 & 0 & 0\end{array}$

106.057459
255.6686783

vapor flow @ jet discharge (lb/hr) =

$\mathrm{H} 2 \mathrm{O}=$

$\mathrm{H} 2 \mathrm{Ol}=$

$\mathrm{HNO3}=$

$\mathrm{HNO} I=$

NOX $=$

$\mathrm{SO} 2=$

$\mathrm{FeCl} 3=$

$\mathrm{NaF}=$

$\mathrm{PbO}=$

$(\mathrm{Na}, \mathrm{K}) \mathrm{BO} 2=$

$\mathrm{O} 2=$

$\mathrm{N} 2=$

glass ${ }^{*}=$

temp $(\mathrm{oC})=$

pressure ("wc vac) =

$\mathrm{MW}(\mathrm{lb} / \mathrm{lbmole})=$

MW dry (Ib/bmole) $=$

$\mathrm{Cp}(\mathrm{Btu} / \mathrm{b} / \mathrm{F})=$

total moisture $(\mathrm{b} / \mathrm{hr})=$

moisture $(w \%)=$

$\mathrm{lb}$ H2O / lb dry gas =

volumetric flow $(\mathrm{acfm})=$

$$
(\text { scfm })=
$$

solids loading (grain/scf) $=$

off-gas line I.D. (in) =

off-gas velocity $(\mathrm{ft} / \mathrm{sec})=$

32.30201891

236.7745136

0.004942281

0.00158426

52.04507951

171.3150534

106.057459

26.8063623

28.84

0.280369899

32.30201891

12.63465033

0.144618552

80.09254046

$\mathbf{5 7 . 0 5 4 5 5 0 6 8}$

0.013345646

2.067

57.28393499

check max moisture content:

H2O PS eqn slope $(p s i a / O C)=$

H2O PS eqn intercept (psia) =

max moisture limit $(\mathrm{l} b / \mathrm{hr})=$
0.279
-15.335
No Limit
86.28809445

29.91485422

0

108.1803509

223.976652

33.02311629

0

1.007413405

0.369037226

0.008388503

0.002008752

6.58182E-05

0.003706711

0.001243627

44.28130976

145.2488883

0.03147357

108.1809501

2.5

26.56406508

28.85456996

0.286224035

34.03052969

15.19639649

0.179195174

71.19053454

50.43073408

0.089062536

2.067

50.28479284

0.279

$-15.335$

192.4200312

50.91702584

0.279
Idling w/ FC Stm

(Clemson Run 5\&6)

22.74653155

24249.55064

$-1995579.099$

76.7657245

76.7657245

4.104454912

0

104.8071252

251.2229925

80.2903331

0

0

0

0

0

0

0.004942281

0.00158426

39.82744844

131.0986844

104.8071252

2.5

24.19654725

28.84

0.324527568

80.2903331

31.96061723

0.469737025

86.90082142

62.10927161

0.012259519

2.067

62.1533663

0.279

$-15.335$

No Limit

gamma emitter loading (grain/scf): 


\section{Appendix B. Results of Am/Cm Vitrification Flowsheet Calculations}

(8/97, A.S. Choi)

$\mathrm{Am}-241$
$\mathrm{~Np}-239$
total gamma to scrubber (Ci/hr) $=$


$\mathrm{Cm}-244$
$\mathrm{Cm}-242$
$\mathrm{Pu}-238$
$\mathrm{Pu}-239$
$\mathrm{Pu}-240$

total alpha to scrubber $(\mathrm{Ci} / \mathrm{hr})=$

Quencher / Scrubber:

pressure drop in quencher $(\mathrm{wc})=$

quencher outlet pressure (psia) $=$

temperature approach $(o C)=$

$w t \%$ overall dust removal $=$

overall of $=$

$w t \%$ semivolatile removal $=$

semi-volatile DF =

fresh motive fluid flow $(\mathrm{lb} / \mathrm{hr})=$

$(\mathrm{gpm})=$

fresh motive fluid temp $(o C)=$

assumed outlet vapor $T(O C)=$

H2O PS eqn slope (psia/oC) $=$

H2O PS eqn intercept (psia) =

estimated condensation $(\mathrm{b} / \mathrm{b} / \mathrm{hr})=$

parameter $\mathrm{L}=$

parameter $\mathrm{U}=$

parameter $\mathrm{A}=$

parameter $\mathbf{B}=$

parameter $\mathrm{C}=$

cal'd vapor outlet temp $(o C)=$

cal'd liquid outlet temp $(O C)=$

moisture condensed $(\mathrm{lb} / \mathrm{hr})=$

$\%$ moisture condensed $=$

total vapor discharge $(\mathrm{lb} / \mathrm{hr})=$

\author{
Idling @ 1450 oC \\ (Clemson Run 1\&2)
}

$\mathrm{m}-241=$

p-239 =

$\mathrm{Cm}-244$

$m-242$

Pu-239

$-240$

(1) 


\section{Appendix B. Results of Am/Cm Vitrification Flowsheet Calculations}

\section{(8/97, A.S. Choi)}

\begin{tabular}{rr} 
& \multicolumn{1}{c}{$\begin{array}{c}\text { Idling @ 1450 oC } \\
\text { (Clemson Run 1\&2) }\end{array}$} \\
$\mathrm{O} 2=$ & 52.04507951 \\
$\mathrm{~N} 2=$ & 171.3150534 \\
glass * & 0 \\
$\mathrm{MW}(\mathrm{lb} / \mathrm{bmole})=$ & 27.63608717 \\
$\mathrm{Cp}($ Btu/lb/F) $=$ & 0.257311637 \\
volumetric flow (acfm) $=$ & 61.81245663 \\
$(\mathrm{scfm})=$ & 52.1315941 \\
solids loading (grain/scf) $=$ & 0.014605918
\end{tabular}

gamma emitter loading (grain/scf):

total gamma to HEME (Ci/hr) =

alpha emitter loading (grain/scf);

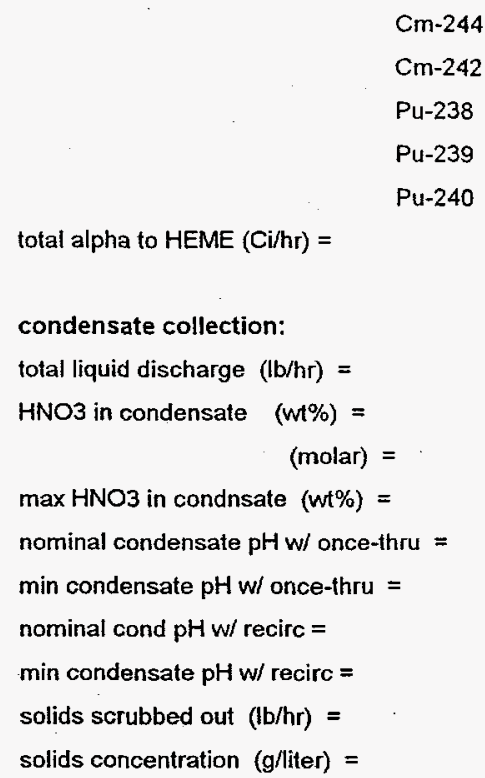

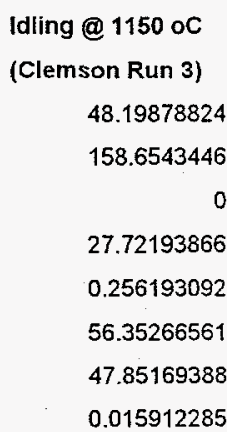

Idling@1150 oC

(Clemson Run 3)

48.19878824

158.6543446

27.72193866

0.256193092

56.35266561

47.85169388

0.015912285

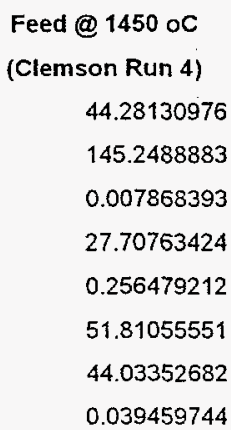

Feed @ 1450 oC

(Clemson Run 4) 44.28130976 145.2488883 0.007868393 27.70763424 0.256479212 51.81055551 44.03352682 0.039459744

9.70403E-07 2.28662E-06 2.93269E-05 $1.82765 E-11$ 0.138027683

0.000163232 1.25038E-09 5.42758E-07 2.32825E-07 8.08523E-06 2.26285933

1114.829246

1115.020258

1519.989339 0.066277663 0.010515762 0.108396337 1.978159266 1.764511843 0.097117164 $-0.116530259$ 0.023605178 0.015523185

23011.03996 23259.58937
28081.3122 28296.63276
Idling w/ FC Stm

(Clemson Run 586)

39.82744844

131.0986844

26.81455169 0.268372928 53.62924689 43.62028499 0.017455865

8.71585E-07$$
0
$$$$
0
$$$$
0
$$

0.012823125

1555.693712

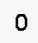

0

0

7

7 


\section{Appendix B. Results of Am/Cm Vitrification Flowsheet Calculations}

(8/97, A.S. Choi)

\author{
Idling@1450 oc \\ (Clemson Run 18.2) \\ Idling@ 1150 oc \\ (Clemson Run 3)
}

Feed @ 1450 oC

Idling w/ FC Stm

(Clemson Run 4)

(Clemson Run 586)

max elemental in COT after 1 feed batch ( $g /$ /iter): (assuming $100 \%$ carryover)

$$
\begin{aligned}
& \mathrm{Pu}= \\
& \mathrm{Am} / \mathrm{Cm}=
\end{aligned}
$$

max successive feed batches =

condensate collection tank (CCT):

nominal liquid volume (liter) $=$

max allow, liquid volume (liter) =

total condnsate per batch (liter) =

req'd transfer rate $(\mathrm{gal} / \mathrm{min})=$

max time w/o transfer $(\mathrm{min})=$

OG temperature drop in COT (oC) =

COT pressure control:

25 psig control air flow (lb/hr) =

$$
\text { @ temp }(o C)=
$$

off-gas flow to HEME (lb/hr) =

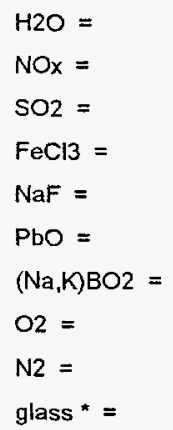

temp $(0 \mathrm{C})=$

Cp $(B t u / l b / F)=$

pressure ("wc vac) =

MW (lb/lbmole) $=$

MW dry (lb/lbmole) $=$

volumetric flow $(\mathrm{acfm})=$

(dry $\mathrm{acfm})=$

$$
(\mathrm{scfm})=
$$

solids loading $($ grain $/ \mathrm{scf})=$

off-gas line 1.D. (in) =

off-gas velocity $(\mathrm{ft} / \mathrm{sec})=$

gamma emitter loading (grain/scf):

total gamma to HEME (Ci/hr) =

alpha emitter loading (grain/scf):
27.63608717

60.02944894

53.35013066

52.1315941

0.014605918

$$
2.067
$$

42.93437355
221.7542558

14.89459643

\section{0}

0

0

0

0.004942281

0.00158426

48.19878824

158.6543446

35.36591019

0.256193092

27.72193866

28.84

54.71915097

49.06486563

47.85169388

0.015912285

2.067

39.13633241
203.9637075

14.04119038

0.369037226

0.008388503

0.002008752

6.58182E-05

0.003706711

0.001243627

44.28130976

145.2488883

0.007868393

35.48023436

0.256469317

2.5

27.70763424

28.85456996

50.30913478

44.98346479

44.03352682

0.039459744

2.067

35.98219247

9.70403E-07

2.28662E-06

2.93269E-05

1.82765E-11

0.138027683
N/A

N/A

N/A

110

180

N/A

N/A

N/A

10

0

35

195.5292809

24.59662143

0

0

0

0

0.004942281

0.00158426

39.82744844

131.0986844

0

48.96484714

0.268372928

3.5

26.81455169

28.84

52.14395186

42.38287244

43.62028499

0.017455865

2.067

37.29449374

8.71585E-07

0

0

0

0.012823125 


\section{Appendix B. Results of $\mathrm{Am} / \mathrm{Cm}$ Vitrification Flowsheet Calculations}

\section{(8/97, A.S. Choi)}

\begin{tabular}{|c|c|c|c|c|c|}
\hline & & $\begin{array}{l}\text { Idling@ } 1450 \text { oc } \\
\text { (Clemson Run 1\&2) }\end{array}$ & $\begin{array}{l}\text { Idling @ } 1150 \text { oC } \\
\text { (Clemson Run 3) }\end{array}$ & $\begin{array}{l}\text { Feed @ } 1450 \text { oc } \\
\text { (Clemson Run 4) }\end{array}$ & $\begin{array}{l}\text { Idling w/ FC Stm } \\
\text { (Clemson Run 5\&6) }\end{array}$ \\
\hline & $\mathrm{Cm}-244$ & 0 & 0 & 0.000163232 & 0 \\
\hline & $\mathrm{Cm}-242$ & 0 & 0 & $1.25038 \mathrm{E}-09$ & 0 \\
\hline & Pu-238 & 0 & 0 & $5.42758 \mathrm{E}-07$ & 0 \\
\hline & Pu-239 & 0 & 0 & $2.32825 E-07$ & 0 \\
\hline & Pu-240 & 0 & 0 & 8.08523E-06 & 0 \\
\hline total alpha to HEME $(\mathrm{Ci} / \mathrm{hr})=$ & & 0 & 0 & 2.26285933 & 0 \\
\hline \multicolumn{6}{|l|}{ High Efficiency Mist Eliminator: } \\
\hline overall dust $\mathrm{DF}=$ & & 40 & 40 & 40 & 40 \\
\hline semivolatiles DF & & 40 & 40 & 40 & 40 \\
\hline add water flush $?$ ( $0=$ false, $1=$ true) & & 0 & 0 & 0 & 0 \\
\hline water flush $(\mathrm{lb} / \mathrm{hr})=$ & & 0 & 0 & 0 & 0 \\
\hline atomizing air flow $(\mathrm{lb} / \mathrm{hr})=$ & & 0 & 0 & 0 & 0 \\
\hline HEME outlet pressure ("wc vac)= & & 13 & 12 & 11.5 & 12.5 \\
\hline \multicolumn{6}{|l|}{ check for possible condensation (1): } \\
\hline assumed outlet vapor $T(O C)=$ & & 45.4 & 44 & 44.4 & 58.2 \\
\hline temperature approach $(\mathrm{oC})=$ & & 0 & 0 & 0 & 0 \\
\hline H2O PS eqn slope $(p s i a / o C)=$ & & 0.0807 & 0.0807 & 0.0807 & 0.163 \\
\hline H2O PS eqn intercept (psia) $=$ & & -2.157 & -2.157 & -2.157 & -6.89 \\
\hline estimated condensation $(\mathrm{lb} / \mathrm{hr})=$ & & 0.945287317 & 0.90014024 & 0.887091603 & 0.796259241 \\
\hline parameter $L=$ & & 576.108579 & 575.3902733 & 575.4497219 & 582.4617205 \\
\hline parameter $U=$ & & 157.0382103 & 144.1460202 & 132.6499155 & 131.3998989 \\
\hline parameter $A=$ & & 11.5909941 & 10.63366461 & 9.787972984 & 19.69084222 \\
\hline parameter $\mathrm{B}=$ & & -8805.786131 & -8060.664866 & -7423.04543 & -14656.36279 \\
\hline parameter $\mathbf{C}=$ & & 375714.3635 & 334170.2425 & 310588.4765 & .785779 .2919 \\
\hline cal'd vapor outlef temp $(O C)=$ & & 45.37711596 & 44.01231802 & 44.44591154 & 58.15767034 \\
\hline cal'd liquid outlet temp $(O C)=$ & & 45.37711596 & 44.01231802 & 44.44591154 & 58.15767034 \\
\hline moisture condensed $(\mathrm{b} / \mathrm{b} / \mathrm{hr})=$ & & 0.967939266 & 0.889077813 & 0.849115185 & 0.873549449 \\
\hline liquid return to COT $(\mathrm{lb} / \mathrm{hr})=$ & & 0.967939266 & 0.889077813 & 0.849115185 & 0.873549449 \\
\hline \multirow[t]{11}{*}{ off-gas to HEPA heater $(\mathrm{lb} / \mathrm{hr})=$} & & 239.8651301 & 220.8588147 & 203.1000713 & 194.649368 \\
\hline & $\mathrm{H} 2 \mathrm{O}=$ & 16.50483401 & 14.00551862 & 13.1920752 & 23.72307198 \\
\hline & NOx $=$ & 0 & 0 & 0.369037226 & 0 \\
\hline & $\mathrm{SO} 2=$ & 0 & 0 & 0.008388503 & 0 \\
\hline & $\mathrm{FeCl} 3=$ & 0 & 0 & $5.02188 \mathrm{E}-05$ & 0 \\
\hline & $\mathrm{NaF}=$ & 0 & 0 & $1.64546 \mathrm{E}-06$ & 0 \\
\hline & $\mathrm{PbO}=$ & 0.000123557 & 0.000123557 & $9.26678 \mathrm{E}-05$ & 0.000123557 \\
\hline & $(\mathrm{Na}, \mathrm{K}) \mathrm{BO} 2=$ & $3.96065 \mathrm{E}-05$ & $3.96065 E-05$ & $3.10907 \mathrm{E}-05$ & 3:96065E-05 \\
\hline & $02=$ & 52.04507951 & 48.19878824 & 44.28130976 & 39.82744844 \\
\hline & $N 2=$ & 171.3150534 & 158.6543446 & 145.2488883 & 131.0986844 \\
\hline & glass * $=$ & 0 & 0 & 0.00019671 & 0 \\
\hline temp $(O C)=$ & & 36.74726736 & 35.36591019 & 35.48023436 & 48.96484714 \\
\hline $\mathrm{Cp}(\mathrm{Btu} / \mathrm{b} / \mathrm{F})=$ & & 0.256538155 & 0.255417315 & 0.255671858 & 0.267563213 \\
\hline MW (lb/bmole) & & 27.69572717 & 27.78215231 & 27.77001727 & 26.87341119 \\
\hline volumetric flow (a & $(\mathrm{acfm})=$ & 61.02846043 & 55.62637991 & 51.12983602 & 52.98438385 \\
\hline & $(\mathrm{scfm})=$ & 51.8102613 & 47.55654121 & 43.75169296 & 43.33028737 \\
\hline solids loading (gra & rain/scf) $=$ & 0.000367413 & 0.000400276 & 0.000992848 & 0.000439317 \\
\hline
\end{tabular}




\title{
Appendix B. Results of $\mathrm{Am} / \mathrm{Cm}$ Vitrification Flowsheet Calculations
}

\section{(8/97, A.S. Choi)}

\author{
Idling@1450 oc \\ Idling @ 1150 oC \\ (Clemson Run 18.2) \\ (Clemson Run 3)
}

Feed @ 1450 oc

(Clemson Run 4)

Idling w/ FC Stm
(Clemson Run 5\&6)

gamma emitter loading (grain/scf):

$$
\begin{aligned}
& \mathrm{Cs}-137= \\
& \mathrm{Eu}-154= \\
& \mathrm{Am}-241= \\
& \mathrm{Np}-239=
\end{aligned}
$$

total gamma to HEPA (Ci/hr) =

alpha emitter loading (grain/sct):

$$
\begin{aligned}
& \mathrm{Cm}-244 \\
& \mathrm{Cm}-242 \\
& \mathrm{Pu}-238 \\
& \mathrm{Pu}_{\mathrm{u}-239} \\
& \mathrm{Pu}-240
\end{aligned}
$$

total alpha to HEPA (Ci/hr) =

HEPA Preheater:

desired gas temp increase $(O C)=$ req'd heater duty (Btu/hr) =

10

1107.622043

1015.400979
500

200

16

$\mathrm{H} 2 \mathrm{O}=$

NOx $=$

$\mathrm{SO} 2=$

$\mathrm{FeCl} 3=$

$\mathrm{NaF}=$

$\mathrm{PbO}=$

$(\mathrm{Na}, \mathrm{K}) \mathrm{BO} 2=$

$\mathrm{O} 2=$

N2 =

glass * =

temp $(o C)=$

$\mathrm{Cp}(\mathrm{Btu} / \mathrm{b} / \mathrm{F})=$

MW (lb/lbmole) =

volumetric flow (acfm) =

$(\mathrm{scfm})=$

solids loading (grain/scf) $=$

63.48336464
239.8649677

16.50483401

220.8586523

14.00551862

\section{0}

0

0

0

6.17785E-07

1.98033E-07

52.04507951

171.3150534

46.74726736

0.256538259

27.69572717

51.8102613

1.83706 E-06
47.55654121

2.00138E-06
2.44163E-08

$5.75336 \mathrm{E}-08$

7.37895E-07

4.59857E-13

0.003450692

4.10708E-06

3.14609E-11

1.36564E-08

5.85811E-09

2.03433E-07

0.056571483

10

934.6855068

500

200

14.5

203.0997003

13.1920752

0.369037226

0.008388503

$2.51094 \mathrm{E}-07$

$8.22728 \mathrm{E}-09$

4.63339E-07

1.55453E- 07

44.28130976

145.2488883

3.9342E-07

45.48023436

0.255671901

27.77001727

53.19182597

43.75169296

3.39062E-06
2.19355E-08

0

0

0

0.000320578

\section{0}

0

0

0

0

0

10

937.4581862

500

200

15.5

194.6492057

23.72307198

0

0

0

0

6.17785E-07

1.98033E-07

39.82744844

131.0986844

0

58:96484714

0.26756335

26.87341119

55.04982123

43.33028737

2.19659E-06

$1.22082 E-10$
$1.15067 E-10$
$1.47579 E-09$
$9.19713 E-16$
$7.9823 E-06$

1.09677E-10

$\mathrm{Cs}-137=$

Eu-154 =

Am-241 =

$N p-239=$

total gamma to air jet $(\mathrm{Ci} / \mathrm{hr})=$

alpha emitter loading (grain/scf):

gamma emitter loading (grain/scf)

0

0
0
0
0
0




\section{Appendix B. Results of Am/Cm Vitrification Flowsheet Calculations}

\section{(8/97, A.S. Choi)}

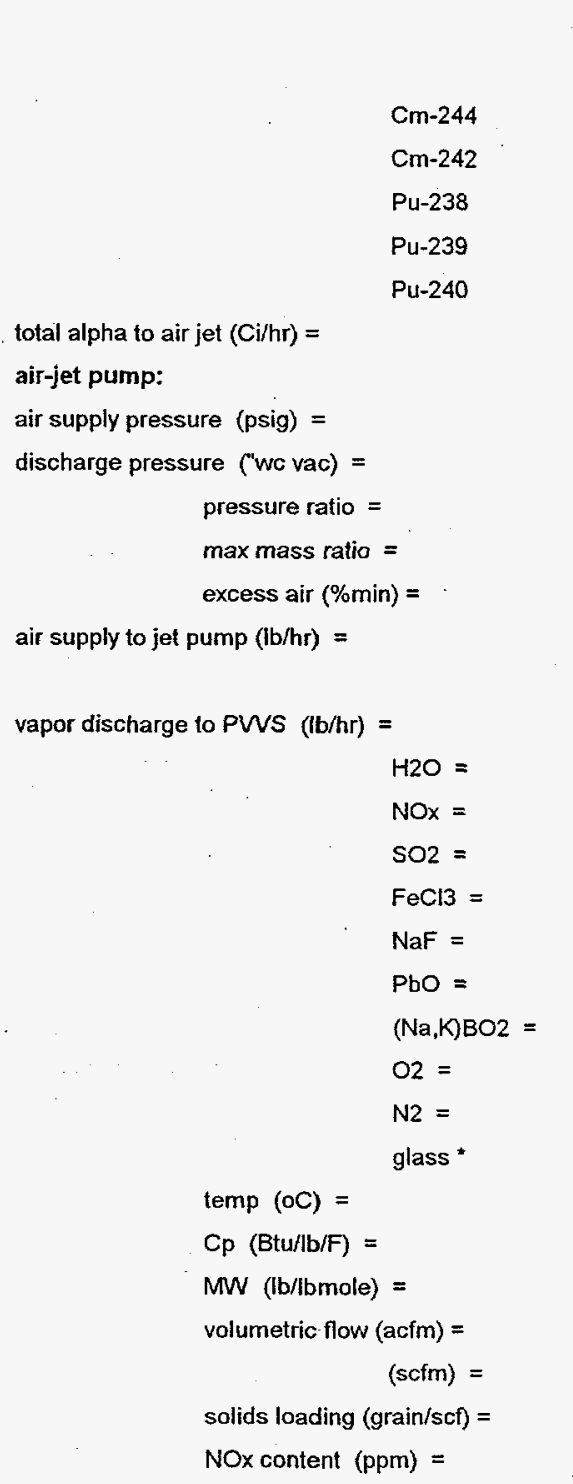
$\begin{array}{cc}\text { Idling@ } 1450 \text { oc } & \text { Idling@1150 oC } \\ \text { (Clemson Run 182) } & \text { (Clemson Run 3) }\end{array}$

0

148.9128554

388.7778231

20.82330682

\section{0}

0

0

0

6.17785E-07 1.98033E-07 85.73697449 282.217541

0

42.33835081

0.253370394

27.94139511

96.61300108

83.2367527

1.14347E-06
Feed @ 1450 oC

(Clemson Run 4)

8.21416E-09

6.29217E-14

2.73127E-11

1.17162E-11

4.06866E-10

0.000113143

25

46.16805171

2.841618931

70

132.1288034

352.9874557

17.83725391

0

0

0

0

6.17785E-07

1.98033E-07

78.0932507

257.0569502

41.55446326

0.252741163

27.9907117

87.34681644

75.440935

1.26163E-06

47.76005349

2.896540454

70

119.200645

322.3003453

16.6488939

0.369037226

0.008388503

2.51094E-07

8.22728E-09

4.63339E-07

1.55453E-07

71.25074502

234.0232794

3.9342E-07

41.67568991

0.252933499

27.98043919

79.81329757

68.90773496

2.15281E-06
Idling w/ FC Stm

(Clemson Run 5\&6)

\section{0}

0

0

0

0

0

25

0

882.2028234

7.75135E-11

7.30598E-11

$9.37026 \mathrm{E}-10$

$5.83955 \mathrm{E}-16$

7.9823E-06

5.21543E-09

$3.9951 \mathrm{E}-14$

1.73417E-11

$7.439 E-12$

$2.58332 E-10$

0.000113143
44.67875972

2.788933689

70

118.6488051

313.2980108

27.16388733

\section{0}

0

0

0

6.17785E-07

1.98033E-07

66.67202857

219.462094

0

50.30719785

0.260255904

27.41287709

81.36145115

68.36986935

1.39212E-06

6.95094E-11

0
0
0

1.60289E-06

total alpha to PWS $(\mathrm{Ci} / \mathrm{hr})=$

Pu-239

Pu-240

miscellaneous calculations: 


\section{Appendix B. Results of $\mathrm{Am} / \mathrm{Cm}$ Vitrification Flowsheet Calculations}

(8/97, A.S. Choi)

$\begin{array}{rrrr}\begin{array}{r}\text { Idling @ } 1450 \text { oC } \\ \text { (Clemson Run 182) }\end{array} & \begin{array}{r}\text { Idling @ } 1150 \text { oC } \\ \text { (Clemson Run 3) }\end{array} & \begin{array}{r}\text { Feed @ } 1450 \text { oC } \\ \text { (Clemson Run 4) }\end{array} & \begin{array}{r}\text { Idling w/ FC Stm } \\ \text { (Clemson Run 5\&6) }\end{array} \\ \text { N/A } & \text { N/A } & 1135.232039 & \text { N/A } \\ \text { N/A } & \text { N/A } & 317.1094645 & \text { N/A } \\ \text { N/A } & \text { N/A } & 167.5771529 & \text { N/A } \\ & \text { N/A } & 0.000488291 & \text { N/A } \\ \text { N/A } & & & \text { N/A } \\ \text { N/A } & \text { N/A } & 0.004851797 & \text { N/A } \\ \text { N/A } & \text { N/A } & 0.002045153 & \text { N/A } \\ \text { N/A } & \text { N/A } & 0.002400723 & \text { N/A } \\ \text { N/A } & \text { N/A } & 0.000389411 & \text { N/A } \\ & \text { N/A } & 1.65103 E-05 & \text { N/A } \\ \text { N/A } & & & \text { N/A } \\ \text { N/A } & \text { N/A } & 0.051377408 & \text { N/A } \\ \text { N/A } & \text { N/A } & 0.051318036 & \text { N/A } \\ \text { N/A } & \text { N/A } & 1.61072 E-05 & \text { N/A } \\ \text { N/A } & \text { N/A } & 3.61189 E-05 & \text { N/A } \\ \text { N/A } & \text { N/A } & 5.54952 E-08 & \end{array}$

Its

Idling@ 1450 oC

NA
N/A

N/A

N/A

N/A

N/A

N/A

N/A

N/A

N/A

N/A

N/A

N/A campaign duration @ 100\% attain. (hr) = total glass produced $(\mathrm{kg})=$

total NOx release to PWS (Ib) $=$

total $\mathrm{Pb}$ release to PWS (b) $=$

total gamma to PWS $(\mathrm{Ci})=$

Cs-137 =

Eu-154 $=$

$\mathrm{Am}-241=$

$\mathrm{Np}-239=$

total alpha to PVS $(C i)=$
$\mathrm{Cm}-244$

Cm-242

Pu-238

Pu-239

Pu-240 